\title{
Progress in designing and delivering effective fishing industry-science data collection in the UK
}

Stephen C. Mangi ${ }^{1 *}$, Sven Kupschus², Steven Mackinson ${ }^{3}$, Dale Rodmell ${ }^{4}$, Alexandra Lee $^{2}$, Elizabeth Bourke ${ }^{4}$, Tom Rossiter ${ }^{5}$, Jim Masters ${ }^{6}$, Stuart Hetherington ${ }^{2}$, Thomas Catchpole ${ }^{2}$, and David Righton ${ }^{2}$

${ }^{1}$ Centre for Environment, Fisheries \& Aquaculture Science, Unit $11^{\text {st }}$ Floor, Baylys Wharf Fish Quay, Plymouth, Devon, PL4 0LH, UK.

${ }^{2}$ Centre for Environment, Fisheries \& Aquaculture Science, Pakefield Road, Lowestoft, NR33 OHT, UK.

${ }^{3}$ Scottish Pelagic Fishermen's Association, Heritage House, 135-139 Shore Street, Fraserburgh, Aberdeenshire, AB43 9BP, UK.

${ }^{4}$ National Federation of Fishermen's Organisations, 30 Monkgate, York YO31 7PF, UK.

${ }^{5}$ Succorfish Ltd, 10 Outlands Road, Cottingham, Hull HU16 4PP, UK.

${ }^{6}$ Fishing into the Future, Unit C041, Brixham Laboratory, Freshwater Quarry, Brixham, TQ5 8BA, UK.

Suggested running title: Industry-science data collection

*Corresponding author: Stephen Mangi, Centre for Environment, Fisheries \& Aquaculture Science (Cefas), Unit $11^{\text {st }}$ Floor, Baylys Wharf Fish Quay, Plymouth, Devon, PL4 OLH, UK Tel: +44(0) 1752 226296. Email: Stephen.mangi@cefas.co.uk 


\begin{abstract}
This study was undertaken to address the increasing need for a strategic approach to industryscience data collections in the face of reducing resources and growing need for evidence in fisheries management. The aim was to evaluate progress in the development of plans and procedures that can be employed to collect, record and use fishing industry knowledge and data in the evidence-base for managing fisheries. This was achieved by reviewing industryled data initiatives already undertaken or ongoing within the United Kingdom to document how these projects have/are incorporating fishing industry data into the process of management decision making; canvassing stakeholder opinion on data gaps and whether these could be filled by data gathered by commercial fishing vessels; establishing what issues might prevent or stimulate commercial fishing vessels in collecting data when they have the opportunity; and describing guidance on a step-by-step process for gathering scientific information such that fishers are empowered to collect the right data, at the right times and in the right format for their fishery. Given recent advances in the collection, interpretation and application of fishery-dependent data, we compare progress made in the UK to other areas of the world. We conclude that there is considerable evidence of a paradigm shift from the conventional practice of scientists asking fishers to provide data for scientific analyses towards full engagement of key stakeholders in data collection.
\end{abstract}

Key words Collaborative research, data collection protocol, fisheries dependent data, fisheries management, incentives, stakeholder engagement 


\section{Contents}

\section{Introduction}

\section{Lessons from past initiatives}

2.1 Literature review

2.2 Key attributes of industry-led data collection

2.2.1 Drivers

2.2.2 Data required, scale and timeline

2.2.3 Funding and research partners

2.2.4 Role of fishers and incentives

2.2.5 Objectives met and why

2.2.6 Impact, strengths, weaknesses, opportunities and threats

2.3 Summary of lessons learnt from past initiatives

2.3.1 Industry participation

2.3.2 Trust and understanding

2.3.3 Incentives

2.3.4 Leadership

2.3.5 Resources

2.3.6 Feedback

3 Matching data needs and capacity to collect data

3.1 Stakeholder interviews

3.2 Data collection and analysis

3.3 Data opportunities and need

3.4 Concerns of fishers

3.5 Concerns of data / advice users

3.6 Engagement

3.7 Summary of matching needs and capacity to collect data

\section{Data collection protocol}

4.1 Guidelines for industry-science data collection

4.2 Application of the data collection protocol

\section{How UK progress compares to other countries}

\section{Conclusion}

Acknowledgements

\section{References}




\section{Introduction}

The demand for data and knowledge on marine resources to underpin management decisions is increasing. The ecosystem approach to management requires knowledge of how marine ecosystems function and being able to predict, with some reliability, their productive capacity and the consequences of management actions (Jennings, 2005; Sherman et al., 2005; Greenstreet \& Rogers, 2006). This necessitates information on (i) the marine environment to understand its state and the impacts of various pressures such as climate change, fishing, and anthropogenic inputs (Pikitch et al., 2004); (ii) marine biodiversity to support development and implementation of marine planning and protection of vulnerable or sensitive marine habitats and species (Pikitch et al., 2004; Sale et al., 2005; Sherman et al., 2005); and (iii) the sustainability of fisheries to strengthen the evidence base and assessment approaches for target species, and to deliver legislation and political commitments such as the Data Collection Framework (DCF) (Jennings, 2005; Frid et al., 2006; Apitz et al., 2006; EC, 2008). Fisheries are also increasingly recognized as an integrated system with ecological, economic, social, and institutional aspects that require interdisciplinary approaches and a more participatory governance structure (Stephenson et al., 2016). Further, there is increasing uncertainty in resource management resulting from the impact of climate change on many marine ecosystem components (Littell et al., 2011; Payne et al., 2016). These challenges, and the expanding objectives for sustainability need to be supported by diverse types of information and methods to provide tactical and strategic decisions across multiple spatial and temporal scales.

The effectiveness of fisheries management, whether it is stock management or the management of activities for nature conservation purposes, is dependent on the timely provision of data and evidence. As a minimum, data and information are needed on the biological characteristics (such as age and length distributions of the species), total catch (landings plus discards), ecological data (impacts on habitat, local growth rates) as well as information about fishing effort, fishing efficiency and fleet behaviour. Currently, there are considerable capacity shortfalls in data collection and large knowledge gaps in our understanding of the marine environment that are preventing effective fisheries management (Dorner at al., 2015; Simmonds et al., 2011; Graham et al., 2011). For instance, biological reference points have not been defined for several commercially important fin- and shell-fish, such as brown crab (Cancer pagurus, Cancridae) skates and rays (superorder: Batoidea), preventing the development of management plans (Tully et al., 2006; Pilling et al., 2008; Large et al., 2013). Many data poor (or data limited) stocks are deemed as a 'high risk' by the 
supply chain, whose purchasing and sourcing policies do not allow them to source from such fisheries (Parkes et al., 2010; MRAG, 2010). No matter how sustainable such fisheries might be, whilst they continue to lack evidence they will remain off limits to many suppliers and retailers. The paucity of information on seabed habitats even within designated marine protected areas (MPA) is such that fishing grounds have been closed as a precautionary measure (Agardy et al., 2003; Sale et al., 2005). From the point of view of the fishing industry, the use of precautionary management and decisions on fishing opportunities / access have immediate consequences for fishing businesses' ability to operate (Stephenson et al., 2016; Pita et al., 2016; Kraan et al., 2013).

While the need for better data, improved stock-assessments and real-time fisheries management is growing, research institutes and state-funded research efforts are suffering from reduced funds and capacity. The fishing industry, however, offers a unique opportunity to help fisheries and marine environment monitoring requirements. Case studies on fisheries dependent data (Lordan et al., 2011; Hoare et al., 2011; Uhlmann et al., 2011; Pennington \& Helle, 2011; Roman et al., 2011; Sampson, 2011) show that the fishing industry can play a central role in addressing data gaps across many fisheries. Experiences from the UK involving the fishing industry in the commissioning and implementation of fishery science projects indicate that fishers have a keen interest in helping provide data that may avert unnecessary precautionary measures being implemented (Armstrong et al., 2013). Indeed, when there is insufficient evidence, the application of precautionary management often entails an opportunity-cost in untapped resources (Mangi et al., 2015; 2016; Stephenson et al., 2016; Stram \& Ianelli, 2015). Consequently, industry-led data collection schemes are increasingly being turned toward to supplement existing research programmes or provide information where it is otherwise absent (Neis \& Felt, 2001; Reid \& Hartley, 2006; Johnson \& van Densen, 2007; Johnson, 2007; Mackinson \& Wilson, 2014). These schemes are being encouraged towards regionally coordinated programmes based on sound statistical design principles because they need to be compatible with existing data collection, especially if they are to be combined in some way. While this is encouraging, the transfer of knowledge does not always seem to happen effectively (Rice, 2005), and more effort is required to ensure fishers' knowledge is integrated with knowledge from scientific research and monitoring.

With limited financial resources and evolving assessment / management needs (including management strategy evaluation), delivering the evidence base for sustainable fisheries management requires fishers, scientists and managers to work together in a collaborative way. Here, we define industry-science data collection as the active participation 
and engagement of fishers in data collection. This definition therefore excludes passive participation where scientists, for example, use fishers' vessels as platforms to collect data, such as in the Cefas Observer Programme (Catchpole et al., 2011; 2017; Enever et al., 2010) and many gear-based selectivity trials (e.g. Revill et al., 2006; Anseeuw et al., 2008; Depestele et al., 2008; Catchpole et al., 2006). It is worth noting that the industry is engaged with active fisheries data collection and research more than ever before. Dorner et al. (2015) note that there is a paradigm shift from the conventional practice of scientists asking fishers to provide data for scientific analyses towards full engagement of key stakeholders in data collection. Recent efforts towards industry-science data collection programmes have involved two ICES symposia on fishery dependent information in Rome, Italy in 2014 (Dorner et al., 2015) and in Galway, Ireland in 2010 (Graham et al., 2011). In both conferences, assembled scientists, fishing industry representatives, policy makers, and other stakeholders discussed how to make best use of data and information collected directly by fishers and how to merge that information efficiently with data from other sources. Similarly, recent projects on science-industry partnerships such as Bridging the gap between science and stakeholders (GAP1 and 2) (Mackinson \& Wilson, 2014; Holm et al., 2018) and the Canadian Fisheries Research Network (CFRN) (Thompson \& Stephenson, 2016) have promoted active engagement in the planning and execution of industry-science research. In Europe, the emergence of the principles for Responsible Research and Innovation (RRI), provides compelling reasons to actively involve relevant stakeholders in developing and delivering fitfor-purpose science research projects.

This manuscript addresses the increasing need for a systematic approach to industryled data collection in the face of reducing resources and growing demand for evidence in fisheries management. We explore how to design and deliver effective industry-science data collection programmes by:

1. reviewing industry-led data initiatives already undertaken or ongoing within the UK to document how these projects have/are incorporating fishing industry data into the process of management decision making, with a view to assessing their degree of success and any barriers experienced;

2. canvassing stakeholder opinion on data gaps and whether these could be filled by data gathered by commercial fishing vessels;

3. establishing what issues might prevent or stimulate commercial fishing vessels in collecting data when they have the opportunity; and 
4. describing guidance on a step-by-step process for gathering scientific information such that fishers are empowered to collect the right data, at the right times and in the right format for their fishery.

5. Given recent advances in the collection, interpretation and application of fisherydependent data, we compare progress made in the UK to other areas of the world.

\section{Lessons from past initiatives}

\subsection{Literature review}

A literature review was conducted to document industry-led data initiatives already undertaken or ongoing within the UK. Through emails, fisheries scientists working in close partnership with fishers in the UK were asked to provide details of recent fisheries-dependent data collection projects they have been involved in. Each recipient was asked to provide the name of the project, state whether it was undertaken in close partnership with fishers or completely independently by fishers and provide a report or other outputs from the project. The websites of various organisations (e.g. Cefas www.cefas.co.uk, Marine Scotland Science www.gov.scot/Topics/marine/science) were also searched to identify projects in which collaborative science involving the fishing industry have been undertaken.

A list of the projects / initiatives including the name of the Project Lead was compiled through the information gathered. Each project on the list was reviewed based on its suitability, relevance and availability of evidence to elucidate the key components of a successful industry data collection process but also highlight pitfalls that need to be avoided. To support the review process, a matrix of key attributes common to most initiatives was created and used to analyse the projects (Table 1). Where information for an attribute was missing from the report, telephone and face-to-face interviews were conducted with the Project Lead to gather the information.

A qualitative assessment of the evidence was made from each project, and the findings used to populate a data table. Each of the attributes were analysed to identify features that best contribute to a successful initiative. Furthermore, we sought to condense the 19 attributes into a smaller and simpler set of key characteristics that could be more easily understood and communicated.

\subsection{Key attributes of industry-led data collection}

In total 20 projects from Shetland in the north to the English Channel in the south were identified for analysis. Three of these had missing documents or no person to contact and 
were therefore not reviewed. The remaining 17 were analysed and key information for each attribute extracted and entered onto a matrix (Table 2). These can be summarised into the following attributes.

\subsubsection{Drivers}

The drivers of industry-led data collection initiatives are exogenous, and can be largely broken down to spatial, scientific and changing management contexts. Spatial drivers mainly come from the growing competition for the marine space with other uses such as offshore wind farm developments and marine protected areas (MPA). For example, the Holderness Fishing Industry Group (HFIG) data collection scheme is associated with the Westernmost Rough offshore wind farm owned by Dong Energy (https://plus.google.com/+HfigOrgUk). Similarly, the Lyme Bay fully documented fishery project was in response to the Lyme Bay closed area (Woo et al., 2013). In this regard, fishers have not only used the data collection process to evidence and justify their activities (one that they hope will show where they fish and protect their right to fish in those areas), but also to assess the scale and impact of MPAs. Similarly, a lack of data supporting science has also played an important part in motivating fishers to take part in several projects e.g. SESAMI - Self sampling in the inshore sector (Mangi et al., 2016). Economic drivers, including the categorisation of sharks, skates and rays as data limited stocks resulting in quota restrictions and fishing opportunities, have led skippers to engage in data collection schemes e.g. in Shark By-Watch UK (Hetherington et al., 2016). Changing management contexts such as the Landing Obligation (a new rule under Europe's Common Fisheries Policy (CFP) in which all catches of regulated fisheries are to be landed and counted against quotas of each Member State), requiring full documentation of catch, has led fishers to test the efficacy of remote electronic monitoring (REM) devices (CCTV) as a tool to monitor catch and discards (MMO, 2013; Roberts et al., 2015; https://www.ssmo.co.uk/).

Most of the projects reviewed here sought to address science and policy, and recognised an intrinsic link. Science tends to be long-term and requires the collection of data year after year, and is thus slow to change. Policy may offer more immediate result (particularly if associated with regulatory change) but needs patience and evidence which must be based on scientific information. Fishers have directly collected data for scientists, management authorities (e.g. Marine Management Organisation (MMO), inshore Fisheries Conservation Agencies (IFCAs), Department of Food, Environment and Rural Affairs (Defra)), Science Technical and Economic Committee on Fisheries (STECF), representative 
bodies such as the National Federation of Fishermen's Organisations (NFFO) or local fishing associations and commercial businesses within the supply chain. Society too was found to be a customer - in the form of data and information for traceability or provenance, or to aid understanding of the marine environment and improve the public image of fisheries.

\subsubsection{Data required, scale and timeline}

Data requirement as an attribute varies among the projects reviewed here but is wholly dependent on the objectives of the project. In addition, the available technology used has a considerable influence on the data collected. In most projects, the data required are usually set by the cooperating scientists. However, in some cases the fishers provide the lead e.g. Holderness Fishing Industry Group (HFIG) ongoing work. Most of the initiatives investigated can be best described as pilot projects, or specific targeted projects within a wider programme. The most successful initiatives were found to be the small and local, where the participants felt a commonality with the other participants. Due to funding limitations, most of the projects were short, usually lasting one or two years at the most. Furthermore, earlier initiatives were often pioneering but short-term; their success was limited as a result. A few longer-term initiatives have begun to build time-series and have incorporated the lessons learned from past experiences e.g. the Shetland Shellfish Management Organisation review of progress (https://www.ssmo.co.uk/), the Fisheries Science Partnership (FSP), which albeit focused on short-term individual projects has a long-term approach (https://www.gov.uk/government/organisations/centre-for-environment-fisheries-andaquaculture-science/about/research\#fisheries-science-partnership-fsp), and the Fishing into the Future (http://www.fishingintothefuture.co.uk/) initiative which is laying foundation for a long-term strategic approach.

A spectrum of data collection methods is evident in all the projects. Broadly, they fall into two categories: active and passive participation. Active participation involves fishers altering their normal activity to collect the data. Examples include sampling, surveying, measurement (sexing, ageing), tagging, survival rates, identification of spawning and nursery areas. Passive data collection utilises the fishing operation as an opportunity to collect valuable data and causes no real inconvenience to the fishers themselves but does require their permission and cooperation. Passive collection normally involved the carrying of an observer or the deployment of technology such as CCTV, inshore vessel monitoring system (iVMS), VMS, e-logs, apps or remote sensors. 


\subsubsection{Funding and research partners}

Public funding in one form or another has been important in supporting most of the initiatives (15 out of 17). Findings show that initiatives with longer timelines tend to have private income at their foundation stage and public funding is added on a project by project basis. Overall, the industry-led data collection initiatives reviewed here have been delivered through partnerships of one form or another. Scientists are the most frequent research partners, providing advice and guidance to ensure scientific rigour. Other partners include relevant government agencies, environmental NGO's and private enterprise. In general, project partners have been important in building credibility and ensuring buy-in to the results. There appears to be a need for a mix of partners, ideally fishers, scientists and some form of management. A considerable amount of resource is evident in all the projects investigated. By far the most important professional resource found was scientific support in the form of project design, observers, training and analysis. Tangible resources such as equipment, premises and money are also commonly used. The exact resources deployed varies from project to project and are usually dictated by the objectives and the project budget.

\subsubsection{Role of fishers and incentives}

The main objective that fishers who collected data had in common was one of selfpreservation or betterment. They see data collection not as their primary purpose, but as a necessary adjunct. For instance, in the National Evaluation of Populations of Threatened and Uncertain Elasmobranchs (NEPTUNE) shark, skate and ray scientific by-catch fishery, fishers collected data to increase understanding of porbeagle (Lamna nasus, Lamnidae) spurdog (dogfishes, Squalidae) and common skate (Dipturus batis, Rajidae) distributions in Celtic Sea fisheries (ICES VIIe-j), whilst demonstrating the level of by-catch and on-deck vitality of these zero-TAC (total allowable catch) and prohibited species. In the case of spurdog, the motivation for participation by fishers was the moral principle of reducing spurdog by-catch and subsequent dead discards. A second motivation was to explore the economic opportunity to land what was already dead (Ellis et al., 2015; Hunter et al., 2016).

Fishers in all the selected projects played an important role in establishing the initiative. They contributed to the design of the project and the execution, often carrying observers, participated in training to take measurements, engaged in tagging work, and agreed to provide electronic $\log$ (e-log) data, or carry REM devices. In all cases, the costs of the data collection were subsidised to some extent, varying from provision of the data collection device through to a payment being made to compensate for time lost in collecting 
data. For instance, participants in the catch quota trials received extra quota to offset the cost of behavioural change to avoid discards that could lead to reduced marketable catches. The value of the data collected was noted as an important incentive to the fishers. The rationale behind the incentive being to minimise the chance of choke species (i.e. species that are incidentally caught at a greater quota proportion than the target species) forcing fishers to alter behaviour or forego future fishing opportunities as catches from these studies counted towards the quota.

\subsubsection{Objectives met and why}

These varied on a case by case basis. Some of the consistent reasons for: (i) success include objectives were clear and achieved, fishers were involved from the beginning, there was clear leadership and ongoing support, short-term benefits were identifiable and good communications to manage expectations. ii) failure include objectives were not met because there was lack of consultation with fishers, objectives were poorly defined and too large scale, lack of perceived benefits (no feedback), lack of leadership and support, too many diverse interests involved and fishers "fatigue".

\subsubsection{Impact, strengths, weaknesses, opportunities and threats}

In general, the technical impact of the data collected has been relatively low. However, much has depended on how the objectives were defined. For instance, in the Conservation Credits initiative the impact on cod (Gadus morhua, Gadidae) mortality was low but the project benefited some fishers through the extra days at sea. Due to the innovative and investigative nature of many of the projects, they often meet the objectives. The strengths therefore vary greatly from project to project, but in cases when there is buy-in from fishers, costs were low, and benefits were high. Strong leadership (preferably from both fishers and scientists) is also a key strength is some of the projects, while a feeling of common ownership and goals among fishers and good communications are positive features of others.

The weaknesses also vary greatly, but the most significant ones relate to a top-down approach; no perceived benefits either during or after the project; too many interests involved; no leadership or resource to maintain momentum; and poor communication with the fishers on an on-going basis. The most common opportunities identified include the possibility of creating a time series once baselines have been established. Securing such opportunities in some cases, however, was hampered by participant "fatigue" and funding issues. The possibility of developing communications to increase wider buy-in to the idea of 
industry collection of data was also identified as a key opportunity. In the face of reducing public funding for data collection, it is important that alternative ways to collect data are pursued and promoted. Equally some of the projects identified the opportunity of technology to automate the data collection process and reduce the burden on the fishers, using them as vessels of opportunity rather than research laboratories. One threat identified as substantial was trust - where fishers feared that their data will be used against them. There is a perception that this has happened in the past.

\subsection{Summary of lessons learnt from past initiatives}

The literature review on the most important attributes of an industry-led data collection initiative was used to identify the "must have" or "must avoid" points from across all the initiatives investigated. These were kept at a broad level to make it easier to communicate. The following aspects are considered fundamental ingredients of successful industry-led data collection initiatives as distilled by the authors. Many of these are similar to the good practice messages produced by the GAP (Bridging the gap between science and stakeholders) project (Mackinson et al., 2008; 2015).

\subsubsection{Industry participation}

It may seem obvious, but on-the-ground support must be present for an initiative to succeed. The core idea should originate within the fishing community and normally in response to some issue or challenge. Ideally the industry group should lead or at least share the project lead throughout. An interesting observation was that the most successful projects have a strong shared interest or "glue" within the industry group well before the initiative begins. Consequently, this explains why small scale local initiatives tend to be more successful than larger projects. The pre-existing shared interest enables the group to stay focused in the face of inevitable challenges and issues. The smaller scale may also ensure that the share of responsibility and effort is verifiably equal which tends to enforce the group value of the project.

\subsubsection{Trust and understanding}

An important attribute found consistently among the successful projects was having a shared goal that was both easy to recall and explain and ultimately communicate. It was observed and commented that if the goals are complicated or unclear, the initiative will fail as all the parties will be aiming for different outcomes. As well as undermining the aims of the 
initiative, there is less acceptance of the results under these circumstances, as participants feel betrayed and trust is lost. Trust is all too often hard won and easily lost. As with most projects requiring a voluntary contribution, there is a period of selling the idea. This can be reduced/facilitated by demonstrating how project participants will work together effectively and respectfully. It is critical that during this process, expectations are managed, and unrealistic promises are avoided. Furthermore, it is extremely important that the project team do exactly what they say they will. Minor instances such as not returning a call in a timely manner or forgetting to share a document can become a catalyst for the unravelling of a project.

\subsubsection{Incentives}

Investigating and presenting the incentives for collaboration is an important step for all successful projects to undergo. The incentives should be clear for all parties and not just fishers. They must also be realistic and deliverable. The incentives to cooperate can take many forms. For instance, in the SESAMI project a daily rate was paid to skippers for recording data from their fishing operations (Mangi et al., 2016). It is worth noting that economic incentives do not have to be monetary. Several of the initiatives actively sought to avoid such monetary incentives as it may promote short-term thinking, whilst the goals are often long-term. Many found that this created a conflict amongst fishers and scientists, and had the effect of eroding trust, whilst indirect economic benefits such as provision of equipment or an uplift in quota were deemed to be more appropriate and consistent with the aims of industry-led data collection. To this end, the majority of the initiatives studied report that the assurance of better data and evidence being incorporated into science and management is the single most important incentive to participants.

\subsubsection{Leadership}

There are many facets of leadership, but in terms of industry-led data collection initiatives the most important was having the drive to make things happen. This role is difficult for a working fisher to fulfil and requires a person with strong administrative skills. It may be feasible for a project to be front loaded with support and training. However, experience has shown that there is need for a local activator throughout the lifetime of the initiative. Small technical issues or points need to be addressed quickly, and without the intervention of a local trusted actor the responsibility falls upon the fishers to contact often unknown individuals who are unavailable when fishers have the time and inclination to pursue the issue. 
Experience from past and ongoing projects has shown that this person can also fulfil the role of communicator and assist in maintaining motivation amongst fishers, whilst providing any necessary support.

\subsubsection{Resources}

The move towards increased industry-led data collection is partly driven by the reduction in funding and personnel resources in the face of a growing requirement to provide robust evidence to support appropriate management and market requirements. Here, there is usually an expectation of a significant return on investment, but for small fisheries this may be difficult to find. Fishers collecting data will certainly improve the efficiency of the process and data quality. However, resources are required in training and validating the data so that its quality is known. Consequently, industry-led data collection should not be seen as free science as this could underestimate the true cost and the value added by the fishers. On the contrary, industry-led data collection projects must therefore be properly resourced if they are to deliver the benefits they set out.

\subsubsection{Feedback}

A common perception of fishers following engagement with data collection is that the process is "down to them" and afterwards they are left in the dark as to the outcome and value of their participation. Most successful initiatives have invested considerable time and money into the feedback process, ensuring that fishers get something out of it and that there is an appreciation of their contribution. Fishers need to hear and see that something is happening with their data. There is an innate suspicion that nothing will change, but by demonstrating that their data means something, it gives fishers hope and motivation to undertake and sustain their efforts.

\section{Matching data needs and capacity to collect the data}

\subsection{Stakeholder interviews}

The transition toward ecosystem-based management necessitates a broader perspective of sustainability, requiring approaches for managing through ecosystem change and strategies for mitigating societal impacts - in particular for those whose livelihoods depend on the sea. These needs demand engagement and collaboration between sectors and across borders (Ducrotoy \& Elliott, 1997; Elliott et al., 1999; Read et al., 2001; Borja, 2005; Apitz et al., 2007). For instance, in fisheries management, most people agree that there are weaknesses in 
ICES stock assessments that could be solved with more or better data (Apitz et al., 2006), and that the fleet of fishing vessels at sea presents an opportunity to collect additional data (Mangi et al., 2015; 2016; Graham et al., 2011). However, realising the potential to join up 'need' and 'capacity' is something that is difficult to achieve. As the literature review has demonstrated, the fishing industry has been collaborating with scientists and regulators in projects to collect fisheries and environmental data with some success. These projects, whilst producing useful information and demonstrating that the fishing industry can add value to research survey work, often have had a short life and rarely have been adopted as a routine model. These issues and related constraints need to be addressed to ensure that industryscience projects can collaborate and share knowledge.

To identify opportunities where marine monitoring need and opportunity can be matched, a stakeholder survey was conducted. The objective was to identify the most useful data and the challenges the fishing industry face when contributing to the stock assessment process. Through contacting UK marine monitoring authorities (MMA), environmental nongovernmental organisations (eNGOs), fish processors and retailers, and fishers we aimed to: (i) identify gaps in monitoring data for assessment needs; (ii) canvass opinion on whether these data gaps could be filled by fisheries dependant data; (iii) identify capacity or expertise within the fishing industry to collect data and; (iv) describe difficulties of data users in incorporating the information in assessments and characterize the potential pitfall faced by the industry in collecting such information.

\subsection{Data collection and analysis}

A technical assessment questionnaire was developed and published through the Survey Monkey (www.surveymonkey.com) online portal. Participants were only shown questions relating to their specific activity in the monitoring and assessment process to ensure relevance and to minimise the time needed to complete the survey. A branched survey design was used with questions being dependent on previous answers (Fig. 1). The questionnaire asked respondents to state the focus area of their current employment, classifying themselves as interested in fisheries data/assessments, ecology and biodiversity data/assessments, hydrographic and water quality data/assessments, or other environmental data/assessments. Fishers were asked what data types they could supply information on while data users (MMA, eNGO and fish processors) were asked what data they would be interested in obtaining with assistance from the fishing industry. 
The survey was circulated to a list of 42 'targeted' stakeholders identified by the Celtic Seas Partnership (CSP www.celticseaspartnership.eu/) via a URL link copied into an email invitation. Targeted stakeholders included fishing industry representatives, environmental NGOs, individual experts, statutory nature conservation bodies, fisheries managers (MMO, Defra) and scientists. These were identified through a series of stakeholder workshops under the Celtic Sea Partnership project. Because of the limited number of invited participants and the uncertainty regarding the likely number of targeted responses, the same survey was also made available to anyone interested in responding. Potential 'general' participants were made aware of the public survey through: (i) requesting 'targeted' respondents to forward the survey link to others that they felt might be interested; (ii) circulating the link to the CSPs Fishing for Data (F4D) Group (The fishing 4 data group is a collaboration between fishing industry, eNGOs, retailers and scientists whose overarching goal is to see data gaps preventing effective fishery and conservation management addressed); and (iii) through publicising the survey link via a blog on the Cefas website (www.cefas.co.uk) which explained the purpose of the research and included a link to the general survey. The Cefas twitter account periodically advertised the blog.

Composition of respondents was monitored throughout, and e-mails were sent to encourage specific categories of respondents to participate to balance the coverage across potential data providers and various data users. Two separate URL survey links were circulated, one to targeted stakeholders and another to the general respondents. The links led to the same survey, but the data generated were stored separately allowing for the groups to be analysed separately. The survey was conducted during November and December 2016. Respondents were contacted by phone or e-mail where details were provided if their answers required clarification or further detail was needed to aid the interpretation.

Overall 49 individuals responded to the on-line survey made up of 16 from the target group and 33 from the general group (Table 3). A total of 23 fishers/vessel owners responded, six respondents were from eNGOs, 19 were from marine monitoring authorities and only one fish processor or retailer completed the survey. Fishers were well represented in both the targeted and general group, making up 35\% and 53\% of respondents respectively. Monitoring authority respondents comprised $46 \%$ of the general group and $25 \%$ of the targeted group. Five out of the six eNGO respondents were part of the targeted group. The fish processor who responded was part of the targeted group. 


\subsection{Data opportunities and need}

Results indicate that $77 \%$ of respondents focused on fisheries related data or stock assessments. These were mainly fishers and fish processors. Most monitoring authority respondents (74\%) specialised in fisheries data, but other specialities were represented, with $16 \%$ focussing on hydrographic and water quality data. Two monitoring authority respondents did not focus on any of the provided options and selected the 'other' option describing themselves as focusing on hazardous substances and impact of fishing on conservation features. The focus of the eNGO respondents was broader with $40 \%$ focusing on fisheries data/assessments, $40 \%$ on ecology and biodiversity data/assessments and $20 \%$ on hydrographic and water quality data/assessments.

Offers and requests for fisheries information dominated the data needs. Of the 23 fishers, 17 indicated they could provide data on fish stocks, 16 for fisheries data, 11 for biodiversity from fishing activity, and 16 for acoustic information making up $85 \%$ of the data offers. The fish processor requested only information related to fisheries data, whereas MMA's and eNGOs showed an increasing interest in general environmental information, but still less than $50 \%$.

The results suggest that the greatest opportunity to involve fishers in data collection is in relation to information directly related to fishing activities. Information on fish stocks (proportion retained and discarded) and fisheries activities (gear types, fishing location, depth) ranked highest in the opportunities (from fishers) and need (from management authority and eNGOs) in substantial numbers. This information is practical to collect as it is most aligned with fishing activities so is likely to have minimal impact on fishing operations. There are wide ranging environmental uses for these data from stock assessments of interest to the fishery itself to biodiversity and habitat information.

Acoustic information can also be made available by many fishers, but there were fewer respondents expecting to use this information. Our survey treated these data as a distinct entity belying the fact that it has the potential to be highly informative on stock abundance, but advice users may not fully understand the relevance at the assessment level. Nevertheless, acoustic information and diversity information from fishing activity present good opportunities for cooperation. Because such information is currently poorly represented in assessments, it may well have a greater effect in improving assessments than additional information on fish stocks and fisheries activity. 


\subsection{Concerns of fishers}

Twenty of the 23 fishers had at least one concern regarding the provision of data with five fishers having the maximum of three concerns. The remaining three fishers had either no concerns or skipped this question. The greatest concerns were that data would be used against fishers (13 responses) followed by concerns over diversion of activity from fishing to monitoring. There were no concerns voiced regarding the use of the data by authorities (Fig. 2). No participating fisher registered a concern that authorities may gain information regarding their activities. In part, this is because inspections already extensively supervise the industry, at sea observer programs and vessel monitoring systems provide data on fishers' activity and behaviour. Few fishers thought they had the time or opportunity to collect information in areas other than fishing grounds. The proportion of the time at sea spent on fishing grounds is relatively large and few vessels can afford to be at sea conducting activities other than fishing. The whole point of involving fishers in data collection is to make efficient use of time spent at sea for different purposes so it does not seem sensible to divert vessels from their primary activity, but opportunities may still exist on transits between port and fishing grounds.

The concern from fishers that the information would be used against them varied between the target and general groups. Fewer number of respondents from the target group indicated this as a major concern compared with those from the general group. If this is a real difference between the groups, it is not clear whether this is due to the targeted group having been involved in the discussions as part of the Fishing 4 Data group (having gained some trust) or whether they simply were more likely to participate in the process because of less concern. The survey did not specify what constituted 'against the fishery'. With hindsight, this is an important distinction worthy of future exploration. If fishers are concerned that their data may lead to reduced catches to maintain sustainability, then this will inevitably lead to conflict. Improvements in precision and accuracy are largely independent of the likely change in status outcome which must be accepted prior to participation in data collections. This relates to managing expectation, better data and better management decisions does not mean better fishing opportunities, at least in the immediate/short term, it can mean more restrictions. Interpretation of the data out of scientific context, with the intent to support a particular view or ambition (pseudo-science) must be avoided. Clarifying and discussing these risks is necessary to avoid the erosion of trust and to ensure the longevity of what is a worthwhile and efficient means to improve our understanding of fish, fisheries and the marine environment. 


\subsection{Concerns of data / advice users}

Concerns over using data directly collected by fishers are surprisingly similar across the different data sources and uses. Encouragingly, and in contrast to optional survey comments made by fishers, government and eNGOs are generally positive about the data. Only roughly $10 \%$ of respondents indicated that data was inherently untrustworthy and therefore not suitable for assessment purposes. Roughly $30 \%$ responses suggest that the data could be used with few or minor changes to the assessment methodology, implying that there should be some quick wins. Responses suggest, for most assessments, around $40 \%$ of the concerns could be overcome with some investment from the fishing industry, such as quality of data, reliability of long-term availability and methodological protocol. The remaining 20 to $30 \%$ of responses indicated that the information from fishers is likely to have spatial, temporal or technical biases. These problems are specific to the intended use of the data and would require additional work by stock assessment scientists in conjunction with the industry to ensure that the biases in the new data sources can be appropriately accounted for in the assessment.

Overall, the results are very positive with majority of the problems resolvable, though in most cases at additional cost. Depending on the objective, industry-science data collection schemes are likely to require a long-term commitment and more thought needs to be put into how such activities can be funded. As commented in the survey, collecting data that is not used presents no benefit. At the same time, it must be clear that in stock assessments, in particular, short time series tend to have little effect in changing assessment outcomes and in many cases, they cannot be used until a long enough time series exists.

\subsection{Engagement}

Thirty four of the 49 respondents replied to the question regarding their willingness to help develop means to overcome issues that hinder the use of fishing vessels as platforms for data collection, all but two of them positively. It is not clear why the other 15 respondents did not want to answer the question. Four fishers, four MMA and three eNGO employees were unconditionally willing to participate. This demonstrates that there are both fishers and data users interested in making industry-science data collection work. Over half of the fishers and data users were interested in further efforts to resolve the issues highlighted in this survey. Those responding positively to this question from the MMA group were almost exclusively those with a focus on fisheries. When willing to work on other data sources participants did 
so only in conjunction with fisheries information indicating that for industry-led data collections, the most likely starting point will be working together on fisheries issues.

\subsection{Summary of matching needs and capacity to collect data}

The Celtic Seas Partnership (CSP) requested a survey of its members to assess what steps they could take to develop a strategy for industry led data collection in the context of fisheries and environmental monitoring for the Celtic Seas ecoregion. The limited number of potential respondents (targeted participants) within the group meant that a generalisation of the responses was difficult particularly since the CSP sees the interaction between industry, scientists and management as one of its major ambitions thus potentially predisposing their membership to views not representative of the view of the entire industry. The study therefore attempted to test the wider utility of the lessons learned by also canvassing industry participants from a more independent pool and initially treating the responses separately to investigate whether there were differences in the views of the two groups. Responses from both groups were entirely voluntary and made up of small sample sizes with relatively little power to detect differences amongst the groups. While these shortcomings are not desirable, the information generated has highlighted areas of opportunity where fishers could cooperate in the collection of data towards a comprehensive monitoring program designed to assess the environmental condition of the seas. Fishers indicated that they are capable and willing to collect a variety of marine environmental information identified as a need by management authorities and eNGOs such as biodiversity observations (marine mammals and birds), marine litter, water quality (hydrographic information), and information directly related to the fishery such as fish stocks, biodiversity from fishing activities and fisheries acoustics. Given that available resources are a limiting factor to improved assessments and the need to maximise the impact of industry-led data collection programmes, we suggest prioritising effort in areas where the assessment focus of government scientists and the data opportunities provided by fishers overlap. Data limited species are attracting a lot of attention because advice is needed but difficult to develop (ICES, 2017). For example, many elasmobranch stocks are data-limited and legislative collections are kerbed due to the relatively small proportion of these species in landings (Simpfendorfer et al., 2011; McCully et al., 2013). However, they are considered ecologically important and several species have restrictive fishing opportunities, and so could easily become choke species as the landing obligation is phased in (Rochet et al., 2014). Better data are likely to lead to improved confidence in status 
assessments, which would make the resulting management measures easier to communicate to stakeholders.

There is also a focus on wide ranging species especially where their distribution has changed from historic conditions (Christensen et al., 2003; Perry et al., 2005). There are many such stocks (e.g. cod and anglerfish), but localisation of fisheries mean that there may be limited opportunities for additional, short-term data collection to influence legislative requirements for many demersal species. The real opportunity for additional information that could make a difference to fishers is probably in the pelagic sector, where a better understanding of the stock distribution and its change over time has the potential to lead to more informed decision making for managers and policy. In contrast, for many age-based demersal stock assessments more of the same data would likely lead only to more precise assessments. There will potentially be some gains in fishing opportunities, because as in datalimited stocks, more precision means less precautionary management is needed. It is unlikely to fix concerns over bias, persistent under- or overestimation of stock dynamic parameters. To address such issues new or different data are needed to correct for biases in the assessment such as changes in productivity or natural mortality. Such changes in stock size due to causes other than exploitation are poorly understood, but recent data on environmental conditions are difficult to relate to these historic changes (Shelton \& Mangel, 2011), so that improvements in environmental data collection are unlikely to improve assessments in the short term.

Fishing industry interest, understandably, is likely to focus on traditional stocks such as haddock (Melanogrammus aeglefinus, Gadidae) cod, sole (Solea solea, Soleidae) and plaice (Pleuronectes platessa, Pleuronectidae). If it is decided to make species such as these the focus of data collection efforts because a broader range of fishers would likely benefit, then it is important to manage the expectations. More substantial and longer-term commitments are necessary to make progress for traditional demersal species. Fisheries data collection methods are already standardised and developed to be suitable for use on fishing vessels. Technological developments have largely focused around automating the electronic data capture / evaluation process. Specific methodologies can only be considered once it is clear specifically what data are needed for a particular stock. In the next section, we look at guidelines for industry-science data collection that support the development of industry-led initiatives from the bottom-up, as well as top-down initiatives from managers and scientists. 


\section{Data collection protocol}

\subsection{Guidelines for industry-science data collection}

Results from the stakeholder survey on matching the need and capacity to collect data show that some data users have legitimate concerns regarding the ability of the fishing industry to provide quality-controlled data in a form that is accessible and useful for generating the scientific evidence for advice in management. There are concerns also about the governance of the scientific process and what partnerships with industry mean for the integrity of scientific institutions. Fishers also have their concerns, particularly those that perceive that management bodies are not committed to make use of their data, or management does not react quickly enough on their information. If they do not understand clearly how science is generated and used in management, it can exacerbate their frustration with management, potentially leading to poor compliance with regulation (Mackinson et al., 2017).

Working in partnership therefore benefits both industry and science because the value of science to management is better understood and accepted when the scientific knowledge is co-created (Dickinson et al., 2012; Schläppy et al., 2017). The stakeholder interviews, and review of past and ongoing data collection initiatives also indicate that many fishers are keen to contribute data from their fisheries as scientific evidence to help improve management and stock assessments. Individual motives for this may be complex, but most fishers agree on the long-term goal of securing access to fishing opportunities. Their interest in science is also deeply rooted in a genuine curiosity to know and understand more about what is happening underwater. While the specific details will vary for each fishery, the common features for successful industry-science data collection initiative can be defined (Mackinson et al., 2017).

Based on a series of workshops (http://www.fishingintothefuture.co.uk/industry-datacollection-strategy-and-issues), reviews, conversations with key personnel and relevant agencies, and experiences from past projects (e.g. GAP2), Mackinson et al. (2017) developed a step-by-step guidance to gathering useful and useable scientific information. The aims were to: (i) provide a reference tool to initiate and execute industry-science data collection initiatives which have the highest chances of success; (ii) help scientists understand how to work with industry to enhance scientific knowledge and data; (iii) help fishers understand and contribute to the scientific evidence base for management; and (iv) support manager's need for salient evidence upon which to develop management measures that benefit the sustainability of fisheries. The guidelines support the development of industry-led initiatives from the bottom-up, as well as top-down initiatives from managers and scientists, and everything in-between. 
The whole process is broken down in to five stages (Fig. 3), each prompted by a single question. Stage 1 initiates the data collection process, convening people around the task of specifying the problem and what needs to be achieved to solve it. The data collected must relate directly to a clearly identified management need from the outset. It is advisable to carefully plan for this stage as all subsequent steps will be greatly informed by it. Stage 2 involves the practical planning of the data collection through co-design. Stage 3 involves collecting data on the water and considering survey issues and data analyses. Stage 4 considers how the knowledge gathered can be applied to achieve the desired impact of the study. Stage 5 involves critical evaluation, drawing out lessons for the future. For more details on each stage see the full report at www.fishingintothefuture.co.uk/industry-scienceand-data/survey-protocol-guidelines/.

The detailed guidelines are presented as series of questions relevant at each stage in the data collection. When the guidance is employed in a practical workshop setting, the questions are used to facilitate planning through open discussion pertinent to the problems at hand. Drilling down, more detailed questions can serve as a checklist of items to be reviewed and considered where relevant.

One key aspect in designing and delivering industry-science data collection programmes is having the right tools to assist scientists in making the most out of the information available to them to generate robust scientific evidence, but also to empower fishers to collect relevant data. Industry-science data collections also need to portray the full spectrum of potential contribution ranging from fishers providing information to scientists, to collaboration in research, through to governance arrangements in which fishers contribute knowledge and actively participate in research and management (Stephenson et al., 2016; Mackinson et al., 2011; 2017; Mackinson \& Middleton, 2018). The data collection protocol describes the essentials of what it takes to co-design and co-deliver industry-science initiatives, helping to identify those people and institutions that should be involved, and the roles they need to play. Consideration should be made on how to motivate people's participation by identifying the drivers and incentives that resonate with them. The step-bystep process also involves planning for joint learning and training activities that develop shared understanding, and getting the support of managers and other stakeholders, and making effective communication with a wider audience. The evaluation phase (Stage 5) is meant to look critically at the results and the process and use this learning when planning new initiatives. While focusing on fisheries data collection, the guidance is not restricted to the process of gathering scientific information required for stock assessment. It is equally 
relevant to research on understanding the biology and ecology of species and behaviour of fisheries.

\subsection{Applying the data collection protocol}

To demonstrate how the stages from the data collection protocol can be applied to collect data and feed into a management system, the scientific and governance pathways developed by the Spurdog By-catch Avoidance Programme, were applied retrospectively (Fig. 4). Other examples are provided in the data collection protocol (www.fishingintothefuture.co.uk/industry-science-and-data/survey-protocol-guidelines/). The Spurdog By-catch Avoidance Programme was a science-industry trial to monitor, avoid and reduce spurdog by-catch. Its objective was to develop and evaluate an alternative option to the prohibition of spurdog and prevent a 'choke' to UK fisheries under the CFP landing obligation. Although spurdog is a prohibited species, it is caught in demersal trawl and gillnet fisheries within European waters. Due to its status, current catches of spurdog are discarded, although the extent of this problem is unknown. The new CFP introduced a landing obligation with a phased implementation from 2015. Previously, spurdog was a zero TAC species meaning it had the potential to become choke species in mixed fisheries, whereby it forces fishers to stop fishing altogether and tie-up their vessels in areas where spurdog is caught as by-catch. The recent (2017) addition of spurdog to the prohibited species list has prevented it from becoming a choke species, in effect opting out of fisheries legislation, ensuring that discarding can continue. However, this is not in the spirit of the landings obligation, as it does not contribute to the reduction in fishing pressure of the stock and does not address wasteful dead discarding.

Based on fishery-dependant scientific evidence (Bendall et al., 2014; Hetherington et al., 2016), a collaborative research partnership between government policy advisors, scientists, the fishing industry and an environmental non-governmental organisation (eNGO) informed the development and trial of the real-time avoidance of spurdog. Through an ArcGIS on-line portal, fishers self-report their by-catch in real-time by area. This information is compiled and reported back to fishers using a traffic light system with red (high risk of spurdog by-catch), amber (medium risk of significant by-catch) and green (low risk of significant by-catch). This empowers the fishers to make informed fishing behaviour decisions in real-time, enabling active avoidance of recent by-catch "hotspots", reducing spurdog by-catch, reducing fishing mortality and prevent choking the fishery. By utilising data collected directly by the fishing industry, fishers are more likely to adapt their fishing 
behaviour to avoid spurdog by-catch as the evidence provided is based on their own observations. While the stakeholder engagement helps underpin future decisions on avoiding by-catches in key 'hotspot' areas, facilitating a real-time understanding of the interaction between fishers and this threatened stock, the programme is assessing the feasibility of devolving management of spurdog by-catch to the fishing industry.

The initial phase of the programme has successfully demonstrated that a real-time spurdog by-catch reporting tool, together with a small dead spurdog by-catch allowance, offers a real and probable alternative to an immediate Prohibited Species listing for spurdog, thereby providing a pragmatic solution to align spurdog with the CFP landing obligation (Hetherington et al., 2016). Through continued positive engagement with the European Commission, a strong UK Government policy lead, supported by two positive, but cautious reviews of the Spurdog By-catch Avoidance Programme by Scientific, Technical and Economic Committee for Fisheries (STECF) (STECF, 2014; 2015) led to fishing vessels participating in the project to land limited quantities of dead spurdog, with a precautionary annual limit of 270 tonnes (UK allocation of 100 tonnes), with a vessel monthly limit of 2 tonnes. This incentivised industry participation in the programme, allowing for a comprehensive trial for evaluation.

\section{How UK progress compares to other countries}

While the tide is slowly turning to be more supportive of industry-science initiatives in the UK, there is no overarching policy from science, management or end users that seeks to create and promote the conditions to initiate and implement such activities. What exists is a collection of learning-by-doing cases, each seeking to solve locally relevant issues. Systematic and institutional support for industry-science needs to come from the organisations that have statutory responsibility for collected data, its quality control and application (Mackinson \& Middleton, 2018). Such a situation is better reflected in East coast USA, and in New Zealand and Australia where dedicated programmes for industry-science initiative fall under the auspices of science and management agencies. For example, the NOAA Fisheries National Cooperative Research Program was set up through congressional funding to provide a means for commercial and recreational fishers to become involved in the collection of fundamental fisheries information to support the development and evaluation of management options. Through this programme, the industry and other stakeholders can partner with NOAA fisheries and university scientists, in all phases of the research program, 
including survey/statistical design, conducting of research, analysis of results, and communication of results (https://www.st.nmfs.noaa.gov/cooperative-research/index).

Similarly, in New Zealand the Trident Systems, a limited partnership funded by its partners together with Seafood Innovations Limited, aims to provide high quality research services supporting the effective and efficient management of New Zealand's fisheries for long-term sustainable use. Trident Systems' research and development programme focuses on the delivery of stock-specific services with the work carried out in collaboration with several independent research providers including the Ministry for Primary Industries (http://www.tridentsystems.co.nz/). Its purpose is to (i) develop innovative systems and processes, including for efficient data collection for fisheries management, especially from inshore finfish fisheries; (ii) apply these systems and processes to provide stock and/or fishery-specific research services that support timely and efficient fisheries management decision making; (iii) carry out these activities in a manner that efficiently utilises industry resources, and supports industry involvement in fisheries management processes; and (iv) ensure a broad base of industry commitment to the development of its systems and processes, and the utilisation of the results of applying these systems and processes.

In Australia, the Fisheries Research and Development Corporation (FRDC) is a cofunded partnership between the Australian Government and the fishing and aquaculture sectors (http://www.frdc.com.au/About-us). It was formed as a statutory corporation in 1991, under the provisions of the Primary Industries Research and Development Act 1989 and is responsible to the Minister of Agriculture and Water Resources. The FRDC's role is to plan and invest in fisheries research, development and extension activities and provide leadership and coordination of the monitoring, evaluating and reporting including facilitating dissemination, extension and commercialisation. Although FRDC works with a diverse and geographically dispersed group of stakeholders, the key ones are aquaculture, commercial fishing, indigenous fishing and recreational fishing sectors.

In Europe, The Netherlands, Denmark and Norway have ongoing programmes where scientists are working closely with industry on routine data collection programmes. For example, the Dutch self-sampling programme coordinated by the Institute for Marine Resources and Ecosystem Studies (IMARES) undertakes discards monitoring in close collaboration with the Dutch fishing industry (Kraan et al., 2013). Within this project, a reference fleet of vessel owners, willing to participate in a self-sampling programme, has been recruited to provide key evidence to support management of discarding practices. In 2013, the reference fleet consisted of 23 vessels. Similarly, the Norwegian reference fleet, 
funded through an annual quota set aside for the Institute of Marine Research (IMR), comprises of 20 vessels in the coastal demersal, 11 vessels in the offshore demersal, two vessels in the coastal pelagic and five vessels in the offshore pelagic fisheries that systematically delivers assessment ready data on a range of stocks (Bowering et al., 2011; Pennington \& Helle, 2011; Nedreaas et al., 2006). The Norwegian reference fleet is a source of information and data to a range of stakeholders including the Institute of Marine Research (IMR), the Ministry of Fisheries and Coastal affairs (FKD), the Directorate of Fisheries (FDIR), the National Institute of Nutrition and Seafood Research (NIFES), the International Council for the Exploration of the Sea (ICES), and the Norwegian Fishermen Organization (Norges Fiskarlag).

Recent appointments of former government scientists by the demersal and pelagic industry sectors from several EU countries and Norway demonstrate industry's commitment to professionalism in undertaking their role within the established systems that collect and make use of scientific data. For instance, in a landmark development, the representative association for Scotland's mackerel and herring fishers appointed a chief scientific officer to spearhead marine research to boost understanding of key pelagic fish stocks and improve their management (http://www.scottishpelagic.co.uk/). This appointment by the Scottish Pelagic Fishermen's Association (SPFA) represents an innovative new approach to fisheries management where fishing vessels will play a significant role in collecting and disseminating scientific information on fish stocks.

The programmes and initiatives described above demonstrate how global marine environmental governance and the management of fisheries during the last decade has been building opportunities for scientists, fishers, policy makers and stakeholders to communicate, negotiate and work together (Johnson, 2007; Neis \& Felt, 2001; Reid \& Hartley, 2006). They also indicate growing efforts in the mainstreaming of fishing industry generated data for fisheries and marine science evidence and decision-making. While the objectives of the initiatives vary, they all endeavour to provide legitimacy and equitable management, costefficient research, and more efficient enforcement due to higher legitimacy among stakeholders. The expansion of the programmes shows that it takes a structured and balanced approach to mobilise key actors by matching their strategic interests and indicates that collaborative research is one principle route to providing data and information for evidencebased decision-making. These initiatives encompass a model for data provision that could be routinely adopted to overcome some of the funding limitations and short-term nature of current industry-led data collection projects. 


\section{Conclusion}

This study was undertaken to address the increasing need for a strategic approach to industryscience data collections in the face of reducing resources and growing need for evidence in fisheries management and marine environmental monitoring. The aim was to evaluate progress in the development of plans and procedures that can be employed to collect, record and use fishing industry knowledge and data in the evidence-base for managing fisheries and marine ecosystems. Here, opportunities where fishers could cooperate in the collection of data towards a comprehensive monitoring program have been identified and matched with the needs of monitoring agencies. Further, guidelines for data collection, as well as the management and administration of the use of the data (i.e. storage, ownership and accessibility of the data) that is subsequently collected have been described. There are still barriers to achieving a routine industry-science data collection scheme that feeds data into stock assessment and management advice. These include cultural challenges (e.g. where monitoring schemes and stock assessments are not yet flexible enough to utilise fisheries dependant data) and lack of resources (both financial and organisational) to adequately fund and run such programmes and uncertainty around the long-term commitment to collecting these data. However, the research conducted here has addressed some of the technical and capacity barriers to enable the fishing industry to perform a key role in addressing data gaps in the science and management of fisheries. If fishers can be supported to collect the right data, about the right fisheries, and in the right way, then current data shortages could be overcome.

Our research also addresses issues of fishers-science interactions, engagement and collaborative efforts that could be used to improve trust and relationships. The need for collaboration as well as addressing the practical aspects of data collection mean that the roles people play and the way they interact with one another are key to determining success in industry-science initiatives. At the same time, the twin processes of developing the scientific rigour and content are inseparable. These twin-strands of practical science (i.e. defining the aims, requirements, design and process for the actual data collection) and the collaborative process (i.e. establishing a framework for how the industry and scientists will work together to co-create, co-design, co-deliver and con-construct the knowledge harvested from the research) are mutually supportive. Indeed, the engagement process is unique to collaborative industry-science research while the practical design is relevant to any kind of data collection, and therefore the two processes should run in parallel. Careful attention is therefore needed on how to work together effectively and respectfully. 
A wide range of scientific information that could reasonably be collected by the fishing industry within their normal activities has been identified and matched with advice/policy data needs. For each of the suggested data types there were fishers able to provide such information and data users interested in obtaining the said information. The industry proposed to assist in collection of most if not all data types, but information directly related to the fishery such as fish stocks, biodiversity from fishing activities, fisheries activity and fisheries acoustics was readily obtainable by many of the fishers. Opportunities to maximise the impact of industry-science data collection scheme in the areas of fisheries mean much more detailed discussions between specific fisheries and stock assessment scientists are necessary. Advice could focus on areas of high assessment priority which could also have a beneficial outcome for the industry. These include data collections on data poor species managed on a highly precautionary basis, especially those that may act as choke species as the landing obligation is further implemented. Widely distributed species with changing distributions that complicate the attribution of landings to stock and areas provide further opportunities. In contrast to stock assessments, environmental assessments are less specific. Such data collections could be applied more generally across an ecoregion with fewer concern over the appropriateness of the spatial range of collections and differences in fishing practices.

\section{Acknowledgements}

This research was funded by the (i) Celtic Seas Partnership (CSP) through the Fishing-4-data initiative on informing the scope of the Celtic Seas fishery stakeholder data collection strategy; (ii) Department of Environment, Food and Rural Affairs (Defra) through the Fisheries Science Partnership (FSP); and (iii) Fishing into the Future (FITF) through a grant from the Seafish Strategic Investment Fund (SIF). We would like to thank the Scottish Pelagic Fishermen's Association (SPFA) for supporting one of the authors. Special thanks to the respondents who took part in the online survey and the workshop participants for their thorough, productive and engaging discussions. 


\section{References}

Agardy, T., Bridgewater, P., Crosby, M.P., Day, J., Dayton, P. K., Kenchington, R., Laffoley, D., McConney, P., Murray, P. A., Parks, J. E., \& Peau, L. (2003). Dangerous targets? Unresolved issues and ideological clashes around marine protected areas. Aquatic Conservation: Marine and Freshwater Ecosystems, 13, 353-367. https://doi.org/10.1002/aqc.583

Anseeuw, D., Moreau, K., Vandemaele, S. \& Vandendriessche, S. (2008). Discarding in beam trawl fisheries: quantification and reduction (preliminary results). ILVO Report, Oostende, Belgium.

Apitz, S. E., Elliott, M., Fountain, M., \& Galloway, T. S. (2006). European Environmental Management: Moving to an Ecosystem Approach. Integrated Environmental Assessment and Management, 2, 80-85. https://doi.org/10.1002/ieam.5630020114 Apitz, S. E., Carlon, C., Oen, A., \& White, S. (2007). Strategic frameworks for managing sediment risk at the basin and site-specific scale. Sustainable Management of Sediment Resources, 3, 77-106. https://doi.org/10.1016/S1872-1990(07)80064-X

Armstrong, M. J., Payne, A. I. L., Deas, B., \& Catchpole, T. L. (2013). Involving stakeholders in the commissioning and implementation of fishery science projects: experiences from the UK Fisheries Science Partnership. Journal of Fish Biology, 83, 974-996. https://doi.org/10.1111/jfb.12178

Borja, A. (2005). The European Water Framework Directive: A challenge for nearshore, coastal and continental shelf research. Continental Shelf Research, 25, 1768-1783. https://doi.org/10.1016/j.csr.2005.05.004

Bell, E. (2013). Under-10m automated shellfish data collection pilot study. MF1226 Cefas Report, 15pp.

Bendall, V. A., Carson, N., Cragg, A., Hetherington, S. J., McGregor, K., O’Brien, C., Riley, A., \& Rendall, J. 2(014). Proposal for UK Pilot Project to develop real-time Spurdog By-catch Avoidance Programme to mitigate choke species and so minimise fishing induced mortality. Working document submitted to the Scientific, Technical and Economic Committee for Fisheries (STECF) - 47th Plenary Meeting.

Bowering, R., Storr-Paulsen, M., Tingley, G., Bjorkan, M., Volstad, J.H., Gullestad, P., \& Lorentsen, E.L. (2011). Evaluation of the Norwegian Reference Fleet. http://www.imr.no/filarkiv/2011/10/evaluation_of_the_norwegian_reference_fleet_fina 1 report august_2011 final_rev_logo.pdf/en 
Caslake, R., Kingston, A., Lart, W., \& Searle, A. (2002). Monitoring of discarding and retention by trawl fisheries in Western Waters by the use of fisher self-sampling. MF806 Defra Report, 32pp.

Catchpole, T. L., Enever, R., Maxwell, D. L., Armstrong, M. J., Reese, A., \& Revill, A. S. (2011). Constructing indices to detect temporal trends in discarding. Fisheries Research, 107, 94-99. https://doi.org/10.1016/j.fishres.2010.10.012

Catchpole, T. L., Revill, A. S., \& Dunlin, G. (2006). An assessment of the Swedish grid and square-mesh codend in the English (Farn Deeps) Nephrops fishery. Fisheries Research, 81, 118-125. https://doi.org/10.1016/j.fishres.2006.08.004

Catchpole, T. L., Ribeiro-Santos, A., Mangi, S. C., Hedley, C., \& Gray T.S. (2017). The challenges of the landing obligation in EU fisheries. Marine Policy, 82, 76-86. https://doi.org/10.1016/j.marpol.2017.05.001

Christensen, V., Guénette, S., Heymans, J. J., Walters, C. J., Watson, R., Zeller, D., \& Pauly, D. (2003). Hundred-year decline of North Atlantic predatory fishes. Fish and Fisheries, 4, 1-24. https://doi.org/10.1046/j.1467-2979.2003.00103.x

Combes, J. \& Lart, W. (2007). Clyde Environment and Fisheries Review and Sustainable Supply Chain Project Report. Clyde Fisheries Development Group, 202pp.

Depestele, J., Polet, H., Van Craeynest, K., \& Vandendriessche, S. (2008). A compilation of length and species selectivity improving alterations to beam trawls. ILVO Report, Oostende, Belgium.

Dickinson, J. L., Shirk, J., Bonter, D., Bonney, R., Crain, R. L., Jason, M. J., Phillips, T., \& Purcell1, K. (2012). The current state of citizen science as a tool for ecological research and public engagement. Frontiers in Ecology and the Environment, 10, 291-297. https://doi.org/10.1890/110236

Dorner, H., Graham, N., Bianchi, G., Bjordal, A., Frederiksen, M., Karp, W. A., Kennelly, S. J., Martinsohn, J. T., Murray, K., Pastoors, M., \& Gudbrandsen, N. H. (2015). From cooperative data collection to full collaboration and co-management: a synthesis of the ICES symposium on fishery-dependent information. ICES Journal of Marine Science, 72, 1133-1139. https://doi.org/10.1093/icesjms/fsu222

Ducrotoy, J. P. \& Elliott, M. (1997). Interrelations between science and policy-making: The North Sea example. Marine Pollution Bulletin, 34, 686-701. https://doi.org/10.1016/S0025-326X(97)00118-5

EC, (2008) European Commission Council Regulation (EC) No 199/2008 of 25 February 2008 concerning the establishment of a Community framework for the collection, 
management and use of data in the fisheries sector and support for scientific advice regarding the Common Fisheries Policy.

Elliott, M., Fernandes, T., \& Jonge, V de. (1999). The impact of recent European directives on estuarine and coastal science and management. Aquatic Ecology, 33, 311-321.

Ellis, J. R., Bendall, V. A., Hetherington, S. J., Silva, J. F., \& McCully Phillips, S. R. (2015). National Evaluation of Populations of Threatened and Uncertain Elasmobranchs (NEPTUNE). Project Report (Cefas), 105 pp.

Enever, R., Revill, A. S., Caslake, R., \& Grant, A. (2010). Discard mitigation increases skate survival in the Bristol Channel. Fisheries Research, 102, 9-15. https://doi.org/10.1016/j.fishres.2009.09.013

Frid, C. J. L., Paramor, O. A. L., \& Scott, C. L. (2006). Ecosystem-based management of fisheries: is science limiting? ICES Journal of Marine Science, 63, 1567-1572. https://doi.org/10.1016/j.icesjms.2006.03.028

Graham, N., Grainger, R., Karp, W. A., MacLennan, D. N., MacMullen, P., \& Nedreaas, K. (2011). An introduction to the proceedings and a synthesis of the 2010 ICES Symposium on Fishery-Dependent Information. ICES Journal of Marine Science, 68, 1593-1597. https://doi.org/10.1093/icesjms/fsr136

Greenstreet, S. P. R. \& Rogers, S. I. (2006). Indicators of the health of the North Sea fish community: identifying reference levels for an ecosystem approach to management. ICES Journal of Marine Science, 63, 573-593. https://doi.org/10.1016/j.icesjms.2005.12.009

Hetherington, S. J., Nicholson, R. E., \& O’Brien, C. M. (2016). Spurdog By-Catch Avoidance Programme. Final report. 52 pp.

Hoare, D., Graham, N., \& Schon, P.J. (2011). The Irish sea data-enhancement project: comparison of self-sampling and national data-collection programmes - results and experiences. ICES Journal of Marine Science 68, 1778-1784. https://doi.org/10.1093/icesjms/fsr100

Holm, P., Hadjimichael, M., Linke, S., Mackinson, S. (2018) (Eds). Collaborative research in fisheries: Co-creating knowledge for fisheries governance in Europe. Springer books in Press.

Hunter, E., Hetherington, S., Ross, E., Scutt Phillips, J., Nicholson, R., Borrow, K., Rutland, L., Donnan, D., Wiggins, J., Righton, D., \& Bendall, V. (2016). Shark By-watch UK 2. Understanding by-catch of elasmobranchs in UK waters: A nationwide programme, a regional approach. Final project report. 
ICES, (2017). Report of the ICES Workshop on the Development of Quantitative Assessment Methodologies based on Life-history traits, exploitation characteristics, and other relevant parameters for stocks in categories 3-6 (WKLIFEVI), 3-7 October 2016, Lisbon, Portugal. ICES CM 2016/ACOM:59. 106 pp.

Jennings, S. (2005). Indicators to support an ecosystem approach to fisheries. Fish and Fisheries, 6, 212-232. https://doi.org/10.1111/j.1467-2979.2005.00189.x

Johnson, T.R. (2007). Integrating fishermen and their knowledge in the science policy process: case studies of cooperative research in the North-Eastern U.S. Dissertation: Rutgers University.

Johnson, T. R. \& van Densen, W. L. T. (2007). The benefits and organization of cooperative research for fisheries management. ICES Journal of Marine Science, 64, 834-840. https://doi.org/10.1093/icesjms/fsm014

Kraan, M., Uhlmann, S., Steenbergen, J., Van Helmond, A. T. M., \& Van Hoof L. (2013). The optimal process of self-sampling in fisheries: lessons learned in the Netherlands. Journal of Fish Biology, 83, 963-973. https://doi.org/10.1111/jfb.12192

Large, P. A., Agnew, D. A, Pérez, J. A. A, Frojána, C.B. et al. (2013). Strengths and weaknesses of the management and monitoring of deep-water stocks, fisheries, and ecosystems in various areas of the world - a roadmap toward sustainable deep-water fisheries in the Northeast Atlantic? Reviews in Fisheries Science, 21, 157-180. http://dx.doi.org/10.1080/10641262.2013.785475

Littell, J. S., McKenzie, D., Kerns, B. K., Cushman, S., \& Shaw, C. G. (2011). Managing uncertainty in climate driven ecological models to inform adaptation to climate change. Ecosphere, 2, https://doi.org/doi:10.1890/ES11-00114.1.

Lordan, C., Cuaig, M. O, Graham, N., \& Rihan, D. (2011). The ups and downs of working with industry to collect fishery-dependent data: the Irish experience. ICES Journal of Marine Science, 68, 1670-1678. https://doi.org/10.1093/icesjms/fsr115

MacGarvin, M. (2014). Project Fishface. Modus Vivendi Report, 26pp.

Mackinson, S., \& Middleton, D. (2018) Evolving the ecosystem approach in European fisheries: Transferable lessons from New Zealand's experience in strengthening stakeholder involvement. Marine Policy, 90, 194-202. https://doi.org/10.1016/j.marpol. 2017.12.001

Mackinson, S., \& Wilson, D. C. K. (2014). Building bridges among scientists and fishermen with participatory action research. In J. Urquart, T. Acott, D. Symes, \& M. Zhao 
(EDs.), Social Issues in Sustainable Fisheries Management (pp 121-137). Springer, Dordrecht, The Netherlands.

Mackinson, S., Raicevich, S., Kraan, M., Magudia, R., \& Borrow, K. (Eds.) (2015). Good practice guide: Participatory Research in Fisheries Science. http://gap2.eu/outputs/prhandbook/

Mackinson, S., Mangi S., Hetherington, S., Catchpole, T., \& Masters, J. (2017). Guidelines for Industry-Science Data Collection: Step-by-step guidance to gathering useful and useable scientific information. Fishing into the Future report to Seafish. 65p.

Mackinson, S., Neville, S., Raicevich, S., \& Clausen, W. L. (Eds.) (2008). Good practice guide to participatory research between fisheries stakeholders and scientists. GAP project deliverable 1, $23 \mathrm{pp}$.

Mackinson, S., Wilson, D. C., Galiay, P., \& Deas, B. (2011). Engaging stakeholders in fisheries and marine research. Marine Policy, 35, 18-24. https://doi.org/10.1016/j.marpol.2010.07.003

Mangi, S. C., Dolder, P. J., Catchpole, T. L., Rodmell, D., \& de Rozarieux, N. (2015). Approaches to fully documented fisheries: practical issues and stakeholder perceptions. Fish and Fisheries, 16, 426-452. https://doi.org/10.1111/faf.12065

Mangi, S. C., Smith, S., \& Catchpole, T. L. (2016). Assessing the capability and willingness of skippers towards fishing industry-led data collection. Ocean \& Coastal Management, 134, 11-19. https://doi.org/10.1016/j.ocecoaman.2016.09.027

McCully, S. R., Scott F., Ellis J. R., \& Pilling G. M. (2013). Productivity and susceptibility analysis: application and suitability for data poor assessment of elasmobranchs in northern European seas. International Commission for the Conservation of Atlantic Tunas (ICCAT), 69, 1679-1698.

MMO, (2013). Catch Quota Trials 2012: Marine Management Organisation Final report. Available from www.marinemanagement.org.uk/fisheries/management/quotas cqt.htm

MRAG, (2010). Towards sustainable fisheries management: international examples of innovation. MRAG Ltd. London: 93 pp.

Nedreaas, K. H., Borge, A., Godoy, H., \& Aanes, S. (2006). The Norwegian reference fleet: co-operation between fishermen and scientists for multiple objectives. ICES CM 2006/N: 0512 pp.

Needle, C. L. \& Catarino, R. (2011). Evaluating the effect of real-time closures on cod targeting. ICES Journal of Marine Science, 68, 1647-1655. https://doi.org/10.1093/icesjms/fsr092 
Neis, B. \& Felt, L. (2001). Finding our sea legs: linking fishery people and their knowledge with science and management. St. John's: ISER Books

Parkes, G., Young, J. A., Walmsley, S. F., Abel, R., Harman J., Horvat, P, Lem, A., Macfarlane, A., Mens M., \& Nolan, C. (2010). Behind the signs - a global review of fish sustainability information schemes. Reviews in Fisheries Science, 18, 344-356. https://doi.org/10.1080/10641262.2010.516374

Payne, M. R., Barange, M., Cheung, W. W. L., MacKenzie, B. R., Batchelder, H. P., Cormon, X., Eddy, T. D., Fernandes, J. A., Hollowed, A. B., Jones, M. C., Link, J. S., Neubauer, P., Ortiz, I., Queiro's, A. M., \& Paula, J. (2016). Uncertainties in projecting climate-change impacts in marine ecosystems. ICES Journal of Marine Science, 73, 1272-1282. https://doi.org/10.1093/icesjms/fsv231

Pennington, M. \& Helle, K. (2011). Evaluation of the design and efficiency of the Norwegian self-sampling purse-seine reference fleet. ICES Journal of Marine Science, 68, 17641768. https://doi.org/doi:10.1093/icesjms/fsr018

Perry, A. L, Low, P. J., Ellis J. R. and Reynolds J. D. (2005). Climate change and distribution shifts in marine fishes. Science, 308, 1912-1915. https://doi.org/10.1126/science.1111322

Pikitch, E. K., Santora, C. E., Babcock, A., Bakun, A., Bonfil, R., Conover, D. O., Dayton, P., Doukakis, P., Fluharty, D., Heneman, B., Houde, E. D., Link, J., Livingston, P. A., Mangel, M., McAllister, M. K., Pope, J., \& Sainsbury, K. J. (2004). Ecosystem-based fishery management. Science, 305, 347-347. https://doi.org/10.1126/science.1098222

Pilling, G. M., Apostolaki, P., Failler, P., Floros, C., Large, P. A, Morales-Nin, B., Reglero, P, Stergiou, K. I., \& Tsikliras, A. C. (2008). Assessment and management of data-poor fisheries. In A. Payne, J. Cotter and T. Potter (Eds.), Advances in Fisheries Science: 50 years on From Beverton and Holt (pp 280-305). Blackwell Publishing.

Pita, P., Fernández-Vidal, D., García-Galdo, J., \& Muino, R. (2016). The use of the traditional ecological knowledge of fishermen, cost-effective tools and participatory models in artisanal fisheries: Towards the co-management of common octopus in Galicia (NW Spain). Fisheries Research, 178, 4-12. https://doi.org/10.1016/j.fishres.2015.07.021

Read, S., Elliott, M., \& Fernandes, T. (2001). The possible implications of the Water Framework Directive and the Species \& Habitats Directive on the Management of Marine Aquaculture. In R. Pea, (Ed.), The implications of directives, conventions and 
codes of practice on the monitoring and regulation of marine aquaculture in Europe (MARAQUA) (pp 58-74). Fisheries Research Services, Aberdeen (UK).

Reid, A. N. \& Hartley, T. W. (Eds) (2006). Partnership for a common purpose: Cooperative Fisheries Research and Management. American Fisheries Society Symposium 52. Proceedings of the Symposium Fisheries Society/Sea Grant Symposium Partnerships for a Common Purpose: Cooperative Fisheries Research and Management held in Anchorage, Alaska, U.S.A., 13-14 September 2005. Bethesda: American Fisheries Society.

Revill, A., Dunlin, G., \& Holst, R. (2006). Selective properties of the cutaway trawl and several other commercial trawls used in the Farne Deeps North Sea Nephrops fishery. Fisheries Research, 81, 268-275. https://doi.org/10.1016/j.fishres.2006.06.017

Rice, J. (2005). Bringing experiential knowledge into fisheries science advisory processes: lessons learned from the Canadian experience of participatory governance. In T. S. Gray (Ed.), Participation in fisheries governance (pp. 249-268). Springer, Dordrecht, The Netherlands.

Roberts, J., Course, G., Pasco, G., \& Sandeman, L. (2015). Catch Quota Trials - South West Beam Trawl. Marine Management Organisation Report, 22pp.

Rochet, M-J., Catchpole, T., \& Cadrin, S. (2014). Bycatch and discards: from improved knowledge to mitigation programmes. ICES Journal of Marine Science, 71, 12161218. https://doi.org/10.1093/icesjms/fsu039

Roman, S., Jacobson, N., \& Cadrin, S. X. (2011). Assessing the reliability of fisher selfsampling programs. North American Journal of Fisheries Management, 31, 165-175. https://doi.org/10.1080/02755947.2011.562798

Rossiter, T. (2016). Fully Documented Fisheries Pilot Project - Welsh whelk fishery. Welsh Government Report, 14pp.

Sale, P. F., Cowen, R. K., Danilowicz, B. S., Jones, G. P., Kritzer, J. P., Lindeman K. C., Planes, S., Polunin, N. V. C., Russ, G. R., Sadovy, Y. J., \& Steneck, R. S. (2005). Critical science gaps impede use of no-take fishery reserves. Trends in Ecology and Evolution, 20, 74-80. https://doi.org/10.1016/j.tree.2004.11.007

Sampson, D. B. (2011). The accuracy of self-reported fisheries data: Oregon trawl logbook fishing locations and retained catches. Fisheries Research, 112, 59-76. https://doi.org/10.1016/j.fishres.2011.08.012 
Schläppy, M-L, Loder, J., Salmond J., Lea A., Dean A. J., \& Roelfsema C. M. (2017).

Making Waves: Marine citizen science for impact. Frontiers in Marine Science, 4,146. https://doi.org/10.3389/fmars.2017.00146

Scientific, Technical and Economic Committee for Fisheries (STECF,) (2014). 47th Plenary Meeting Report (PLEN-14-03). Publications Office of the European Union, Luxembourg, EUR 26944 EN, JRC 93037, 138pp.

Scientific, Technical and Economic Committee for Fisheries (STECF), (2015). 50th Plenary Meeting Report (PLEN-15-03). Publications Office of the European Union, Luxembourg, EUR 27602 EN, JRC 98672, 90pp.

Sheltona, A.O \& Marc Mangela, M. (2011). Fluctuations of fish populations and the magnifying effects of fishing. PNAS, 108, 7075-7080.

https://doi.org/10.1073/pnas.1100334108

Sherman, K., Sissenwine, M., Christensen, V., Duda, A., Hempel, G., Ibe, C., Levin, S., Lluch-Belda, D., Matishov G., McGlade, J., O’Toole, M., Seitzinger, S., Serra, R., Skjoldal, H.-R., Tang, Q., Thulin, J., Vandeweerd, V., \& Zwanenburg K. (2005). A global movement toward an ecosystem approach to management of marine resources. Marne Ecology Progress Series, 300, 241-296. https://doi.org/10.3354/meps300275

Simmonds, E. J., Doring, R., Daniel, P., \& Angot, V. (2011). The role of fisheries data in the development evaluation and impact assessment in support of European fisheries plans. ICES Journal of Marine Science, 68, 1689-1698. https://doi.org/10.1093/icesjms/fsr067

Simpfendorfer, C., Cortés, E., Heupel M., Brooks, E., Babcock, E., Baum, J., McAuley, R., Dudley, S., Stevens, J. D., Fordham, S., \& Soldo, A. (2011). An integrated approach to determining the risk of over-exploitation for data-poor pelagic Atlantic sharks. Report of an expert working group held June 3-6 2008 in Washington DC. 15pp.

Stephenson, R. L., Paul, S., Pastoors, M. A., Kraan, M., Holm, P., Wiber, M., Mackinson, S., Dankel, D. J., Brooks, K., \& Benson, A. (2016). Integrating fishers' knowledge research in science and management. ICES Journal of Marine Science, 73, 1459-1465. https://doi.org/10.1093/icesjms/fsw025

Stram, D. L. \& Ianelli, J. N. (2015). Evaluating the efficacy of salmon bycatch measures using fishery-dependent data. ICES Journal of Marine Science, 72, 1173-1180. https://doi.org/10.1093/icesjms/fsu168

Thompson, S. \& Stephenson, R. L. (Eds.), (2016). Canadian Fisheries Research Network: Final report of NSERC Strategic Network Grant NETGP 389436-09. 
Tully, O., Robinson M., O'Keefe, E., Cosgrove R., Doyle O., \& Lehane B. (2006) The Brown Crab (Cancer pagurus L.) Fishery: Analysis of the resource in 2004 - 2005. Fisheries Resource Series, 4. Irish Sea Fisheries Board, 48pp.

Uhmann, S. S., Bierman, S. M., \& van Helmond, A. T. M. (2011). A method of detecting patterns in mean lengths of samples of discarded fish, applied to the self-sampling programme of the Dutch bottom-trawl fishery. ICES Journal of Marine Science, 68, 1712-1718. https://doi.org/10.1093/icesjms/fsr066

Woo, J., Rossiter, T., \& Woolmer, A. (2013). Lyme Bay Fully Documented Fisheries Trial. Blue Marine Foundation report, 105pp. 
Table 1 Key attributes that formed the basis of data extraction from past / ongoing industryled data collection initiatives.

\begin{tabular}{|c|c|}
\hline Attribute & Details sought \\
\hline Drivers & The reasons behind the inception of the initiative \\
\hline Objectives & What the initiative sought to do? \\
\hline Data required & Data the initiative needed to collect to meet the objectives \\
\hline Scale & How big or small was the initiative? \\
\hline Timelines & When did the initiative take place? \\
\hline Funding & Who paid for the initiative? \\
\hline Partners & Who worked with the fishers to deliver the initiative? \\
\hline Role of fishers & What data were the fishers required to collect? \\
\hline Industry incentives & What incentives were given to the fishers? \\
\hline Resources employed & What resources (people and equipment) were supplied to the fishers? \\
\hline Data collection methods & What methods did the fishers use to collect the data? \\
\hline Data customer & Who was the data collected for? \\
\hline Objectives met - Why? & Were the objectives met and what were the main reasons for this? \\
\hline Address science / Policy & Was the data aimed at addressing science or policy needs? \\
\hline Impact & What, if any, impact did the initiative have? \\
\hline Strength & Key strengths of the initiative \\
\hline Weaknesses & Key weaknesses of the initiative \\
\hline Opportunity & What opportunities were identified to build upon the initiative? \\
\hline Threats & What issues were identified that would prevent future success? \\
\hline
\end{tabular}


Table 2 Summary of the projects / initiatives reviewed and assessment of how they addressed the key attributes of industry-led data collection.

\begin{tabular}{|c|c|c|c|c|c|c|c|c|c|c|c|}
\hline & Project & Objectives & Driver & $\begin{array}{l}\text { Date, scale and } \\
\text { data required }\end{array}$ & $\begin{array}{l}\text { Source of funding } \\
\text { and research } \\
\text { partners }\end{array}$ & Role of fishers & Industry incentives & $\begin{array}{l}\text { Objectives met } \\
\text { and why? }\end{array}$ & Impact & $\begin{array}{l}\text { Link to } \\
\text { management } \\
\text { and decision } \\
\text { making } \\
\end{array}$ & Reference \\
\hline 1 & $\begin{array}{l}\text { Blue Marine } \\
\text { Lyme Bay } \\
\text { fully } \\
\text { documented } \\
\text { fishery }\end{array}$ & $\begin{array}{l}\text { To assess the } \\
\text { scale and impact } \\
\text { of the fishery to } \\
\text { support a } \\
\text { voluntary } \\
\text { management } \\
\text { agreement and } \\
\text { local fishery } \\
\text { managers }\end{array}$ & $\begin{array}{l}\text { Voluntary } \\
\text { agreement, } \\
\text { market Access, } \\
\text { local } \\
\text { management }\end{array}$ & $\begin{array}{l}2013 \text { - ongoing; } \\
\text { Full scale iVMS } \\
\text { / pilot } \\
\text { collection of } \\
\text { catch and effort } \\
\text { (44 vessels) }\end{array}$ & $\begin{array}{l}\text { f80k from EFF \& } \\
\text { Blue Marine } \\
\text { Foundation; } \\
\text { MMO, IFCA, } \\
\text { Plymouth } \\
\text { University, } \\
\text { Succorfish }\end{array}$ & $\begin{array}{l}\text { Sign voluntary } \\
\text { agreement / fit } \\
\text { VMS, record } \\
\text { catch and effort } \\
\text { data }\end{array}$ & $\begin{array}{l}\text { Improved port } \\
\text { facilities / Access to } \\
\text { their data / Access to } \\
\text { market ( } 20 \% \\
\text { premium) / free } \\
\text { equipment }\end{array}$ & $\begin{array}{l}\text { Yes - } \\
\text { developed and } \\
\text { tested a data } \\
\text { collection } \\
\text { template for } \\
\text { inshore fishers }\end{array}$ & $\begin{array}{l}\text { Medium - Data } \\
\text { collection is } \\
\text { ongoing post } \\
\text { project and } \\
\text { data used by } \\
\text { IFCAs }\end{array}$ & $\begin{array}{l}\text { Provision of } \\
\text { catch data and } \\
\text { location. } \\
\text { Mechanism for } \\
\text { compliance and } \\
\text { monitoring } \\
\text { fishing around } \\
\text { sensitive reef } \\
\text { areas }\end{array}$ & Woo et al., 2013 \\
\hline 2 & $\begin{array}{l}\text { Welsh whelk } \\
\text { fishery study }\end{array}$ & $\begin{array}{l}\text { Real time spatial } \\
\text { catch and effort } \\
\text { data collection to } \\
\text { advise } \\
\text { consultation and } \\
\text { calculate CPUE }\end{array}$ & $\begin{array}{l}\text { Implementing a } \\
\text { management } \\
\text { plan }\end{array}$ & $\begin{array}{l}2016 \text { - ongoing; } \\
\text { Pilot prior to } \\
\text { roll out ( } 5 \\
\text { vessels); iVMS, } \\
\text { catch and effort }\end{array}$ & $\begin{array}{l}\text { £10K from central } \\
\text { government; } \\
\text { Welsh Fishermen } \\
\text { Association, } \\
\text { Welsh } \\
\text { Government, } \\
\text { Succorfish }\end{array}$ & $\begin{array}{l}\text { Fit iVMS / } \\
\text { record catch } \\
\text { and effort data } \\
\text { by string. } \\
\text { Provide a daily } \\
\text { landed weight }\end{array}$ & $\begin{array}{l}\text { High quality data } \\
\text { feeding into policy / } \\
\text { free equipment / } \\
\text { build up track record }\end{array}$ & $\begin{array}{l}\text { Yes - collected } \\
\text { and analysed } \\
\text { high resolution } \\
\text { CPUE }\end{array}$ & $\begin{array}{l}\text { High - Data has } \\
\text { fed into Whelk } \\
\text { consultation } \\
\text { and systems to } \\
\text { be introduced } \\
\text { to nationally }\end{array}$ & $\begin{array}{l}\text { Provision of } \\
\text { data towards } \\
\text { consultation on } \\
\text { sustainable } \\
\text { management } \\
\text { measures for } \\
\text { the Welsh } \\
\text { whelk } \\
\text { fishery }\end{array}$ & Rossiter, 2016 \\
\hline 3 & $\begin{array}{l}\text { SESAMI - Self } \\
\text { sampling in } \\
\text { the inshore } \\
\text { sector }\end{array}$ & $\begin{array}{l}\text { To test capability, } \\
\text { willingness and } \\
\text { practicalities of } \\
\text { data collection by } \\
\text { skippers }\end{array}$ & $\begin{array}{l}\text { Need for more } \\
\text { and better } \\
\text { (under } 10 \mathrm{~m} \text { ) } \\
\text { data that } \\
\text { fishers can trust } \\
\text { to provide } \\
\text { evidence on } \\
\text { their fishing } \\
\text { practices }\end{array}$ & $\begin{array}{l}\text { 2012-2014,SE } \\
\text { and SW of } \\
\text { England (30 u10 } \\
\text { vessels); catch, } \\
\text { effort, gear } \\
\text { type, fishing } \\
\text { location, } \\
\text { discards }\end{array}$ & $\begin{array}{l}£ 200 k \text { from Defra } \\
\text { and EFF; Cefas, } \\
<10 \mathrm{~m} \text { fishers }\end{array}$ & $\begin{array}{l}\text { Collect data } \\
\text { daily via paper } \\
\text { log-sheet and } \\
\text { carry observers } \\
\text { on occasion for } \\
\text { validation }\end{array}$ & $\begin{array}{l}\text { Better data provided } \\
\text { to scientists; daily } \\
\text { rate }\end{array}$ & $\begin{array}{l}\text { Yes - compiled } \\
\text { a dataset with } \\
\text { total catch } \\
\text { from inshore } \\
\text { fleet }\end{array}$ & $\begin{array}{l}\text { The trial } \\
\text { demonstrated } \\
\text { that validated } \\
\text { self-sampling } \\
\text { by under } 10 \mathrm{~m} \\
\text { skippers is } \\
\text { potentially, an } \\
\text { efficient way of } \\
\text { collecting } \\
\text { commercial } \\
\text { fishery data. }\end{array}$ & $\begin{array}{l}\text { Approaches for } \\
\text { fully } \\
\text { documented } \\
\text { fisheries in the } \\
\text { inshore fleet }\end{array}$ & $\begin{array}{l}\text { Mangi et al., } \\
2016\end{array}$ \\
\hline 4 & $\begin{array}{l}\text { Seafish SW } \\
\text { beam self- } \\
\text { sampling } \\
\text { project }\end{array}$ & $\begin{array}{l}\text { Fisher self- } \\
\text { sampling effort in } \\
\text { parallel with } \\
\text { normal data } \\
\text { collection by } \\
\text { discard officers to } \\
\text { characterise and } \\
\text { compare the two } \\
\text { types of sampling }\end{array}$ & $\begin{array}{l}\text { Cost / need for } \\
\text { better data } \\
\text { leading to } \\
\text { better science }\end{array}$ & $\begin{array}{l}2000-2001 ; \text { SW } \\
\text { England (317 } \\
\text { hauls from } 14 \\
\text { vessels); Catch } \\
\text { including } \\
\text { discards }\end{array}$ & $\begin{array}{l}\text { DEFRA and } \\
\text { Seafish; Seafish, } \\
\text { fishers }\end{array}$ & $\begin{array}{l}\text { Sampling catch, } \\
\text { sorting, record } \\
\text { volumes and } \\
\text { label discard } \\
\text { sample to be } \\
\text { handed over to } \\
\text { Discard officer }\end{array}$ & $\begin{array}{l}\text { Better data / natural } \\
\text { interest and } f 25 \\
\text { payment per sample } \\
\text { taken }\end{array}$ & $\begin{array}{l}\text { Yes - data } \\
\text { gathered and } \\
\text { compared. } \\
\text { Fishers were } \\
\text { well trained } \\
\text { and supported. }\end{array}$ & $\begin{array}{l}\text { Low as the } \\
\text { initiative } \\
\text { stopped at the } \\
\text { end of the } \\
\text { project but did } \\
\text { show what } \\
\text { could be } \\
\text { achieved }\end{array}$ & $\begin{array}{l}\text { Monitoring of } \\
\text { discarding and } \\
\text { retention by } \\
\text { trawl fisheries } \\
\text { in Western } \\
\text { Waters } \\
\text { by the use of } \\
\text { Fisher Self } \\
\text { Sampling. }\end{array}$ & $\begin{array}{l}\text { Caslake et al., } \\
2002\end{array}$ \\
\hline
\end{tabular}




\begin{tabular}{|c|c|c|c|c|c|c|c|c|c|c|c|}
\hline 5 & $\begin{array}{l}\text { Clyde } \\
\text { Fisheries } \\
\text { Development } \\
\text { Project }\end{array}$ & $\begin{array}{l}\text { Define a baseline } \\
\text { from which a } \\
\text { sustainable } \\
\text { fishery } \\
\text { management plan } \\
\text { could be } \\
\text { implemented }\end{array}$ & $\begin{array}{l}\text { Environmental } \\
\text { pressures, } \\
\text { misinformation } \\
\text { and declining } \\
\text { catches }\end{array}$ & $\begin{array}{l}\text { 2007-08; } \\
\text { Observers (fleet } \\
\text { wide self- } \\
\text { sampling); } \\
\text { Retained and } \\
\text { discarded by } \\
\text { species }\end{array}$ & $\begin{array}{l}\text { £300k from FIFG, } \\
\text { Seafish, Private; } \\
\text { Fishers, } \\
\text { processors, NGO, } \\
\text { Trade bodies, } \\
\text { Academia }\end{array}$ & $\begin{array}{l}\text { Carry observers } \\
\text { and undertake } \\
\text { self-sampling }\end{array}$ & $\begin{array}{l}\text { Better data feeding } \\
\text { management / } \\
\text { improved quality and } \\
\text { prices / engagement } \\
\text { with industry }\end{array}$ & $\begin{array}{l}\text { yes - sufficient } \\
\text { resource on } \\
\text { the ground } \\
\text { and all fishers } \\
\text { engaged }\end{array}$ & $\begin{array}{l}\text { Provided a } \\
\text { baseline for the } \\
\text { fishery. } \\
\text { Improved } \\
\text { quality } \\
\text { standards. Has } \\
\text { been } \\
\text { subsequently } \\
\text { used by science } \\
\text { and in policy }\end{array}$ & $\begin{array}{l}\text { Resources and } \\
\text { outreach - all } \\
\text { fishers were } \\
\text { contacted }\end{array}$ & $\begin{array}{l}\text { Combes \& Lart, } \\
2007\end{array}$ \\
\hline 6 & $\begin{array}{l}\text { Holderness } \\
\text { Fishing } \\
\text { Industry } \\
\text { Group (HFIG) } \\
\text { ongoing work }\end{array}$ & $\begin{array}{l}\text { Provide a baseline } \\
\text { on shellfish } \\
\text { activity and } \\
\text { establish a plan } \\
\text { for monitoring } \\
\text { changes following } \\
\text { construction of } \\
\text { offshore } \\
\text { windfarm }\end{array}$ & $\begin{array}{l}\text { Dong Energy } \\
\text { license } \\
\text { application for } \\
\text { Westernmost } \\
\text { Rough offshore } \\
\text { windfarm }\end{array}$ & $\begin{array}{l}2013 \text { and 2014; } \\
\text { Surveys at fixed } \\
\text { points; Data on } \\
3 \text { shellfish } \\
\text { stocks within } \\
\text { proposed and } \\
\text { control inshore } \\
\text { and offshore } \\
\text { areas }\end{array}$ & $\begin{array}{l}\text { Commissioned by } \\
\text { Dong; Holderness } \\
\text { Fishing Industry } \\
\text { Group }\end{array}$ & $\begin{array}{l}\text { HFIG tendered } \\
\text { for project and } \\
\text { fishers involved } \\
\text { in designing of } \\
\text { surveys }\end{array}$ & $\begin{array}{l}\text { Baseline to negotiate } \\
\text { mitigation/compensa } \\
\text { tion }\end{array}$ & $\begin{array}{l}\text { Yes - buy in } \\
\text { from both } \\
\text { sides }\end{array}$ & $\begin{array}{l}\text { Provided a } \\
\text { means of } \\
\text { resolving } \\
\text { potential } \\
\text { conflicts and } \\
\text { measuring } \\
\text { future change }\end{array}$ & $\begin{array}{l}\text { Data accepted } \\
\text { by both Dong } \\
\text { Energy and } \\
\text { HFIG and } \\
\text { provided basis } \\
\text { for improved } \\
\text { relations }\end{array}$ & $\frac{\text { https://plus.goog }}{\underline{\text { le.com/+HfigOrg }}}$ \\
\hline 7 & $\begin{array}{l}\text { North Sea real } \\
\text { time cod } \\
\text { closures }\end{array}$ & $\begin{array}{l}\text { Reduce cod } \\
\text { mortality to gain } \\
\text { exemptions from } \\
\text { the Cod Recovery } \\
\text { Plan }\end{array}$ & $\begin{array}{l}\text { Restrictions on } \\
\text { fishing activity } \\
\text { through limited } \\
\text { days at sea }\end{array}$ & $\begin{array}{l}2009 \text { - ongoing; } \\
\text { North Sea and } \\
\text { West of } \\
\text { Scotland; } \\
\text { Abundance of } \\
\text { cod in hauls }\end{array}$ & $\begin{array}{l}\text { Various sources } \\
\text { (EFF, Scottish } \\
\text { Government); } \\
\text { Chiefly SWFPA } \\
\text { and MSS, later SFF }\end{array}$ & $\begin{array}{l}\text { Fishers } \\
\text { identified areas } \\
\text { of cod } \\
\text { abundance } \\
\text { which were } \\
\text { then analysed } \\
\text { by scientists }\end{array}$ & $\begin{array}{l}\text { Additional days at } \\
\text { sea }\end{array}$ & $\begin{array}{l}\text { Yes, in terms } \\
\text { of days at sea: } \\
\text { unclear in } \\
\text { terms of } \\
\text { reduction in } \\
\text { mortality }\end{array}$ & $\begin{array}{l}\text { Difficult to } \\
\text { judge given } \\
\text { large areas } \\
\text { involved }\end{array}$ & $\begin{array}{l}\text { Encouraged } \\
\text { industry to } \\
\text { become more } \\
\text { selective } \\
\end{array}$ & $\begin{array}{l}\text { Needle \& } \\
\text { Catarino, } 2011\end{array}$ \\
\hline 8 & $\begin{array}{l}\text { North Sea } \\
\text { (English) CCTV }\end{array}$ & $\begin{array}{l}\text { To test efficacy of } \\
\text { CCTV as a tool to } \\
\text { monitor catch and } \\
\text { discard activity in } \\
\text { North Sea cod } \\
\text { fishery and any } \\
\text { variations e.g. } \\
\text { length frequency } \\
\text { measurement }\end{array}$ & $\begin{array}{l}\text { Excessive } \\
\text { discards and a } \\
\text { desire by fishing } \\
\text { industry to land } \\
\text { more of what } \\
\text { they catch }\end{array}$ & $\begin{array}{l}\text { 2012-2015; } \\
\text { North Sea (17 } \\
\text { vessels); } \\
\text { Automatic and } \\
\text { continuous } \\
\text { catch data }\end{array}$ & $\begin{array}{l}\text { f400K from } \\
\text { Central } \\
\text { government; } \\
\text { Fishers, MMO, PO }\end{array}$ & $\begin{array}{l}\text { To carry the } \\
\text { CCTV } \\
\text { equipment and } \\
\text { fish more } \\
\text { selectively for } \\
\text { cod }\end{array}$ & $\begin{array}{l}\text { Uplift in quota based } \\
\text { on historic discard } \\
\text { levels }\end{array}$ & $\begin{array}{l}\text { Yes - The } \\
\text { motivation and } \\
\text { incentives for } \\
\text { fishers were } \\
\text { sufficient and } \\
\text { the technology } \\
\text { fit for purpose }\end{array}$ & $\begin{array}{l}\text { Reduced cod } \\
\text { discards to } \\
\text { around } 1 \% \\
\text { from a normal } \\
\text { level of } 40 \%\end{array}$ & $\begin{array}{l}\text { Accuracy in } \\
\text { catch } \\
\text { monitoring } \\
\text { tools }\end{array}$ & MMO, 2013 \\
\hline 9 & $\begin{array}{l}\text { Channel Sole } \\
\text { CCTV }\end{array}$ & $\begin{array}{l}\text { To test efficacy of } \\
\text { CCTV as a tool to } \\
\text { monitor catch and } \\
\text { discard activity in } \\
\text { SW fishery and } \\
\text { year on year } \\
\text { variations }\end{array}$ & $\begin{array}{l}\text { Excessive } \\
\text { discards and a } \\
\text { desire by fishing } \\
\text { industry to land } \\
\text { more of what } \\
\text { they catch }\end{array}$ & $\begin{array}{l}2011 \text { - 2013; } \\
\text { English Channel } \\
\text { (11 vessels); } \\
\text { Automatic and } \\
\text { continuous } \\
\text { catch data }\end{array}$ & $\begin{array}{l}\text { f250k from } \\
\text { central } \\
\text { government; } \\
\text { Fishers, MMO, PO }\end{array}$ & $\begin{array}{l}\text { To carry the } \\
\text { CCTV } \\
\text { equipment and } \\
\text { sort plaice } \\
\text { discards and } \\
\text { present them to } \\
\text { the camera }\end{array}$ & $\begin{array}{l}\text { Uplift in quota based } \\
\text { on historic discard } \\
\text { levels }\end{array}$ & $\begin{array}{l}\text { Yes - powerful } \\
\text { tool for } \\
\text { corroborating } \\
\text { self-reporting } \\
\text { data }\end{array}$ & $\begin{array}{l}\text { Much improved } \\
\text { data on } \\
\text { discards and } \\
\text { evidence to } \\
\text { support claim } \\
\text { of low discard } \\
\text { levels }\end{array}$ & $\begin{array}{l}\text { use of Remote } \\
\text { Electronic } \\
\text { Monitoring } \\
\text { (REM) to } \\
\text { corroborate } \\
\text { self-reported } \\
\text { discard data } \\
\end{array}$ & $\begin{array}{l}\text { Roberts et al., } \\
2015\end{array}$ \\
\hline 10 & $\begin{array}{l}\text { Shetland } \\
\text { Shellfish } \\
\text { Management } \\
\text { Organisation - } \\
\text { Review of } \\
\text { progress }\end{array}$ & $\begin{array}{l}\text { To implement } \\
\text { fully functional } \\
\text { management } \\
\text { supported by } \\
\text { sound data for all } \\
\text { shellfish stocks }\end{array}$ & $\begin{array}{l}\text { Establishment } \\
\text { of the } \\
\text { regulating order } \\
\text { and SSMO }\end{array}$ & $\begin{array}{l}2000 \text { - ongoing; } \\
70 \text { vessels; All } \\
\text { data to support } \\
\text { effective } \\
\text { management of } \\
\text { inshore } \\
\text { shellfisheries }\end{array}$ & $\begin{array}{l}\text { Various sources } \\
\text { (self, local council, } \\
\text { central } \\
\text { government, } \\
\text { grants); Local } \\
\text { council, fishers }\end{array}$ & $\begin{array}{l}\text { Management } \\
\text { board / data } \\
\text { collection and } \\
\text { cooperation } \\
\text { with scientists } \\
\end{array}$ & Self-management & $\begin{array}{l}\text { Work in } \\
\text { progress but } \\
\text { positive steps } \\
\text { forward being } \\
\text { made. }\end{array}$ & $\begin{array}{l}\text { Deemed a } \\
\text { successful local } \\
\text { co- } \\
\text { management } \\
\text { initiative with } \\
\text { overwhelming } \\
\text { support } \\
\end{array}$ & $\begin{array}{l}\text { Management } \\
\text { and regulation } \\
\text { of shellfish } \\
\text { within } \\
\text { Shetland's six } \\
\text { mile limit } \\
\end{array}$ & $\begin{array}{l}\text { https://www.ss } \\
\text { mo.co.uk/ }\end{array}$ \\
\hline
\end{tabular}




\begin{tabular}{|c|c|c|c|c|c|c|c|c|c|c|c|}
\hline & & $\begin{array}{l}\text { inside the 6-mile } \\
\text { limit of Shetland }\end{array}$ & & & & & & & & & \\
\hline 11 & $\begin{array}{l}\text { SFF West of } \\
\text { Scotland } \\
\text { Sampling } \\
\text { Project } 2016 \\
\end{array}$ & $\begin{array}{l}\text { Provide a baseline } \\
\text { on whitefish and } \\
\text { Nephrops stocks }\end{array}$ & $\begin{array}{l}\text { Cod Recovery } \\
\text { Plan reductions } \\
\text { in quota and } \\
\text { increasing } \\
\text { pressure from } \\
\text { competing } \\
\text { interests with } \\
\text { marine spatial } \\
\text { planning }\end{array}$ & $\begin{array}{l}\text { 2016; West of } \\
\text { Scotland; Stock } \\
\text { abundance, age } \\
\text { and sex }\end{array}$ & $\begin{array}{l}\text { EFF and Scottish } \\
\text { Government; SFF, } \\
\text { MSS, Aberdeen } \\
\text { University }\end{array}$ & $\begin{array}{l}\text { Fishers carried } \\
\text { out surveys }\end{array}$ & $\begin{array}{l}\text { Possibility of } \\
\text { influencing policy e.g. } \\
\text { MPAs }\end{array}$ & $\begin{array}{l}\text { Baseline } \\
\text { established } \\
\text { due to } \\
\text { sufficient } \\
\text { resources } \\
\text { being } \\
\text { available. }\end{array}$ & $\begin{array}{l}\text { Too soon to } \\
\text { determine }\end{array}$ & $\begin{array}{l}\text { Establishing } \\
\text { baseline data }\end{array}$ & $\begin{array}{l}\text { Kenny Coull, } \\
\text { Project Manager, } \\
\text { Personal } \\
\text { communication }\end{array}$ \\
\hline 12 & $\begin{array}{l}\text { North Sea } \\
\text { Stock Survey }\end{array}$ & $\begin{array}{l}\text { Provide early } \\
\text { information on } \\
\text { the state of stocks } \\
\text { and feed into ICES } \\
\text { assessments }\end{array}$ & $\begin{array}{l}\text { Difference in } \\
\text { perceptions of } \\
\text { stock } \\
\text { abundance } \\
\text { between fishers } \\
\text { and scientists }\end{array}$ & $\begin{array}{l}\text { Pilot } 2002 \\
\text { continued until } \\
\text { 2015; North } \\
\text { Sea; Qualitative } \\
\text { changes in } \\
\text { stock } \\
\text { abundance }\end{array}$ & $\begin{array}{l}\text { NSFC, NSAC, UHI, } \\
\text { SFF, VisNed, } \\
\text { NFFO, CVO, } \\
\text { Rederscentrale, } \\
\text { Danish } \\
\text { Fishermen's } \\
\text { Association }\end{array}$ & $\begin{array}{l}\text { Record } \\
\text { perceived order } \\
\text { of magnitude of } \\
\text { changes in } \\
\text { stock } \\
\text { abundance }\end{array}$ & $\begin{array}{l}\text { Improved } \\
\text { assessments from } \\
\text { ICES corresponding } \\
\text { to fisher's } \\
\text { experiences }\end{array}$ & $\begin{array}{l}\text { No - timetable } \\
\text { to feed into } \\
\text { ICES altered, } \\
\text { scientists } \\
\text { unhappy with } \\
\text { qualitative } \\
\text { nature and low } \\
\text { level of } \\
\text { responses }\end{array}$ & Limited & $\begin{array}{l}\text { Changes over } \\
\text { time }\end{array}$ & $\begin{array}{l}\frac{\text { https://www.naf }}{\text { c.uhi.ac.uk/resea }} \\
\frac{\text { rch/fisheries/fish }}{\text { ers-north-sea- }} \\
\text { stock-survey }\end{array}$ \\
\hline 13 & $\begin{array}{l}\text { Monthly } \\
\text { Shellfish } \\
\text { Activity } \\
\text { Return / } \\
\text { Shellfish E-log } \\
\text { trial }\end{array}$ & $\begin{array}{l}\text { Record activity } \\
\text { and catch of } \\
\text { under } 10 \mathrm{~m} \\
\text { potting and } \\
\text { netting vessels } \\
\text { with shellfish } \\
\text { licences }\end{array}$ & $\begin{array}{l}\text { A lack of } \\
\text { reliable data } \\
\text { supporting } \\
\text { stock } \\
\text { assessment and } \\
\text { management }\end{array}$ & $\begin{array}{l}2006 \text { - ongoing; } \\
\text { All vessels on a } \\
\text { month by } \\
\text { month basis; } \\
\text { Detailed catch } \\
\text { and effort }\end{array}$ & $\begin{array}{l}\text { f60k per year } \\
\text { from Defra; Defra, } \\
\text { MMO, IFCA }\end{array}$ & $\begin{array}{l}\text { Legally required } \\
\text { to complete the } \\
\text { forms and } \\
\text { provide } \\
\text { accurate details }\end{array}$ & $\begin{array}{l}\text { Improved scientific } \\
\text { basis for } \\
\text { management } \\
\text { decisions. }\end{array}$ & $\begin{array}{l}\text { No - a lack of } \\
\text { compliance } \\
\text { from industry } \\
\text { underpinned } \\
\text { by little or no } \\
\text { motivation as } \\
\text { uses of the } \\
\text { data not been } \\
\text { witnessed. }\end{array}$ & $\begin{array}{l}\text { Limited other } \\
\text { than to } \\
\text { demonstrate } \\
\text { that method of } \\
\text { data collection } \\
\text { has not been } \\
\text { effective }\end{array}$ & $\begin{array}{l}\text { Collecting of } \\
\text { critical catch } \\
\text { and effort data }\end{array}$ & Bell, 2013 \\
\hline 14 & Fishface & $\begin{array}{l}\text { To test the } \\
\text { feasibility of using } \\
\text { recreational } \\
\text { water proof } \\
\text { cameras to collect } \\
\text { footage of } \\
\text { commercial } \\
\text { fishing activity on } \\
\text { inshore vessels } \\
\text { for the purpose of } \\
\text { monitoring }\end{array}$ & $\begin{array}{l}\text { A lack of } \\
\text { reliable data } \\
\text { supporting } \\
\text { stock } \\
\text { assessment and } \\
\text { management }\end{array}$ & $\begin{array}{l}2013-14 ;<10 \\
\text { vessels; } \\
\text { Continuous } \\
\text { capture of } \\
\text { video around } \\
\text { the vessel } \\
\text { whilst active }\end{array}$ & $\begin{array}{l}\text { Private, Fishface; } \\
\text { fishers and } \\
\text { Fishface }\end{array}$ & $\begin{array}{l}\text { Install, operate, } \\
\text { maintain the } \\
\text { camera system } \\
\text { and download } \\
\text { the data on a } \\
\text { regular basis }\end{array}$ & $\begin{array}{l}\text { Better data feeding } \\
\text { management, } \\
\text { improved quality and } \\
\text { prices }\end{array}$ & $\begin{array}{l}\text { Yes - the } \\
\text { quality of the } \\
\text { images were } \\
\text { excellent and } \\
\text { the cameras } \\
\text { generally did } \\
\text { collect the } \\
\text { required data. }\end{array}$ & $\begin{array}{l}\text { Limited to date } \\
\text { but has shown } \\
\text { what can be } \\
\text { achieved at a } \\
\text { low cost on } \\
\text { small scale } \\
\text { vessels }\end{array}$ & $\begin{array}{l}\text { Data storage / } \\
\text { transfer. Low } \\
\text { cost high } \\
\text { quality images }\end{array}$ & MacGarvin, 2014 \\
\hline 15 & $\begin{array}{l}\text { Shark By- } \\
\text { Watch UK } 1\end{array}$ & $\begin{array}{l}\text { Improve } \\
\text { knowledge of } \\
\text { shark and ray by- } \\
\text { catch and }\end{array}$ & $\begin{array}{l}\text { Categorisation } \\
\text { as data limited } \\
\text { stock resulting } \\
\text { in quota } \\
\text { restrictions and }\end{array}$ & $\begin{array}{l}\text { 2011; Southern } \\
\text { North Sea, } \\
\text { Greater Thames } \\
\text { Estuary; } \\
\text { Abundance, }\end{array}$ & $\begin{array}{l}£ 80,000 \text { from EFF; } \\
\text { Cefas, }<10 \text { fishers }\end{array}$ & $\begin{array}{l}\text { Tagging and } \\
\text { recording } \\
\text { information, } \\
\text { self-sampling }\end{array}$ & $\begin{array}{l}\text { Improved knowledge } \\
\text { and data available to } \\
\text { fishers }\end{array}$ & $\begin{array}{l}\text { Yes - } \\
\text { knowledge } \\
\text { gathered and } \\
\text { shared through } \\
\text { website }\end{array}$ & $\begin{array}{l}\text { High impact } \\
\text { through } \\
\text { excellent } \\
\text { stakeholder } \\
\text { engagement }\end{array}$ & $\begin{array}{l}\text { Involvement } \\
\text { and use of local } \\
\text { knowledge to } \\
\text { improve } \\
\text { communication }\end{array}$ & $\begin{array}{l}\text { www.sharkbywa } \\
\text { tch.org }\end{array}$ \\
\hline
\end{tabular}




\begin{tabular}{|c|c|c|c|c|c|c|c|c|c|c|c|}
\hline & & $\begin{array}{l}\text { discarding in the } \\
\text { inshore fisheries. }\end{array}$ & $\begin{array}{l}\text { fishing } \\
\text { opportunities }\end{array}$ & $\begin{array}{l}\text { spawning and } \\
\text { nursery areas }\end{array}$ & & & & & $\begin{array}{l}\text { and media } \\
\text { campaign }\end{array}$ & $\begin{array}{l}s \text { and trust } \\
\text { between } \\
\text { fishermen and } \\
\text { scientists }\end{array}$ & \\
\hline 16 & $\begin{array}{l}\text { Shark By- } \\
\text { Watch UK } 2\end{array}$ & $\begin{array}{l}\text { Minimise by-catch } \\
\text { of sharks and rays }\end{array}$ & $\begin{array}{l}\text { Understanding } \\
\text { by-catch and } \\
\text { discards of } \\
\text { elasmobranchs } \\
\text { in UK waters: }\end{array}$ & $\begin{array}{l}\text { 2015; Bristol } \\
\text { Channel, } \\
\text { Greater Thames } \\
\text { Estuary, The } \\
\text { Wash; Level of } \\
\text { by-catch and } \\
\text { discarding / } \\
\text { survival }\end{array}$ & $\begin{array}{l}£ 250,000 \text { from } \\
\text { EFF, Defra, } \\
\text { Morrisons; Cefas }\end{array}$ & Data collection & $\begin{array}{l}\text { Improved evidence } \\
\text { base leading to more } \\
\text { fishing opportunities }\end{array}$ & $\begin{array}{l}\text { Partial - focus } \\
\text { too large }\end{array}$ & $\begin{array}{l}\text { High. excellent } \\
\text { stakeholder } \\
\text { outreach } \\
\text { through } \\
\text { dedicated } \\
\text { comms team. }\end{array}$ & $\begin{array}{l}\text { Species subject } \\
\text { to small or zero } \\
\text { TACs, such as } \\
\text { spurdog, could } \\
\text { become choke } \\
\text { species under } \\
\text { CFP }\end{array}$ & $\begin{array}{l}\text { Hunter et al., } \\
2016\end{array}$ \\
\hline 17 & $\begin{array}{l}\text { National } \\
\text { Evaluation of } \\
\text { Populations } \\
\text { of Threatened } \\
\text { and } \\
\text { Uncertain } \\
\text { Elasmobranch } \\
\text { s (NEPTUNE) } \\
\text { shark, skate } \\
\text { and Ray } \\
\text { Scientific By- } \\
\text { catch Fishery }\end{array}$ & $\begin{array}{l}\text { Increase the } \\
\text { understanding of } \\
\text { the levels of by- } \\
\text { catch and on-deck } \\
\text { vitality for } \\
\text { porbeagle, } \\
\text { spurdog \& } \\
\text { common skate in } \\
\text { Celtic Sea }\end{array}$ & $\begin{array}{l}\text { Listing of } \\
\text { porbeagle, } \\
\text { spurdog \& } \\
\text { common skate } \\
\text { as 0-TAC or } \\
\text { prohibited } \\
\text { during } 2009 \text { - } \\
11 .\end{array}$ & $\begin{array}{l}2012 \text { - 2013; } \\
\text { Celtic Sea; } \\
\text { Catch rates, } \\
\text { abundance, on- } \\
\text { deck vitality, } \\
\text { long-term } \\
\text { discard survival. }\end{array}$ & $\begin{array}{l}\text { Defra; Cefas, } \\
\text { fishers }\end{array}$ & $\begin{array}{l}\text { Self-sampling } \\
\text { after training } \\
\text { trips }\end{array}$ & $\begin{array}{l}\text { Improved evidence } \\
\text { base to feed into } \\
\text { scientific assessment }\end{array}$ & $\begin{array}{l}\text { Overall } \\
\text { objective } \\
\text { was not met as } \\
\text { mechanisms } \\
\text { on who and } \\
\text { where the data } \\
\text { should be used } \\
\text { were not } \\
\text { identified. }\end{array}$ & $\begin{array}{l}\text { Some of the } \\
\text { data were used } \\
\text { by a } \\
\text { subsequent } \\
\text { programme in a } \\
\text { proposal to } \\
\text { STECF for the } \\
\text { Spurdog By- } \\
\text { catch } \\
\text { Avoidance } \\
\text { Programme. }\end{array}$ & $\begin{array}{l}\text { Increased data } \\
\text { collection to } \\
\text { improve } \\
\text { robustness of } \\
\text { available data }\end{array}$ & Ellis et al., 2015 \\
\hline
\end{tabular}


Table 3 Composition of target and general group divided by employer and topic focus as inferenced by respondent's employment details.

\begin{tabular}{|c|c|c|c|c|c|}
\hline Employment focus & $\begin{array}{l}\text { Target } \\
\text { respondent }\end{array}$ & $\begin{array}{l}\% \text { of } \\
\text { target }\end{array}$ & $\begin{array}{l}\text { General } \\
\text { respondent }\end{array}$ & $\begin{array}{l}\text { \% of } \\
\text { general }\end{array}$ & Total \\
\hline Fish processor or retailer & 1 & $6 \%$ & & & 1 \\
\hline Fisheries data or assessments & 1 & $6 \%$ & & & 1 \\
\hline Fisher / vessel owner & 6 & $35 \%$ & 17 & $53 \%$ & 23 \\
\hline Fisheries data or assessments & 5 & $29 \%$ & 16 & $50 \%$ & 21 \\
\hline $\begin{array}{l}\text { Hydrographic and water quality data or } \\
\text { assessments }\end{array}$ & 1 & $5 \%$ & 1 & $3 \%$ & 2 \\
\hline Marine monitoring authority & 4 & $24 \%$ & 15 & $47 \%$ & 19 \\
\hline Fisheries data or assessments & 4 & $24 \%$ & 10 & $31 \%$ & 14 \\
\hline Hazardous substances & & & 1 & $3 \%$ & 1 \\
\hline $\begin{array}{l}\text { Hydrographic and water quality data or } \\
\text { assessments }\end{array}$ & & & 3 & $9 \%$ & 3 \\
\hline Impact of fishing on conservation features & & & 1 & $3 \%$ & 1 \\
\hline Non-Governmental organisation & 5 & $29 \%$ & 1 & $3 \%$ & 6 \\
\hline Ecology and biodiversity data or assessments & 2 & $11 \%$ & 1 & $3 \%$ & 3 \\
\hline Fisheries data or assessments & 2 & $11 \%$ & & & 2 \\
\hline $\begin{array}{l}\text { Hydrographic and water quality data or } \\
\text { assessments }\end{array}$ & 1 & $6 \%$ & & & 1 \\
\hline Total & 16 & & 33 & & 49 \\
\hline
\end{tabular}




\section{List of figures}

Figure 1 Schematic of the branched on-line survey identifying the questions the respondent had to answer to which determined the path through the survey.

Figure 2 Responses registered by fishers regarding concerns with data collections showing the proportion (\%) for the target and general group.

Figure 3 Summary overview of the step-by-step data collection protocol showing the parallel science and collaboration processes, accompanied by the key questions to consider at each stage.

Figure 4 Architecture of the development, trail and evaluation of the real-time Spurdog bycatch avoidance programme demonstrating how the data collection guidelines can be applied to generate data and information for management. 


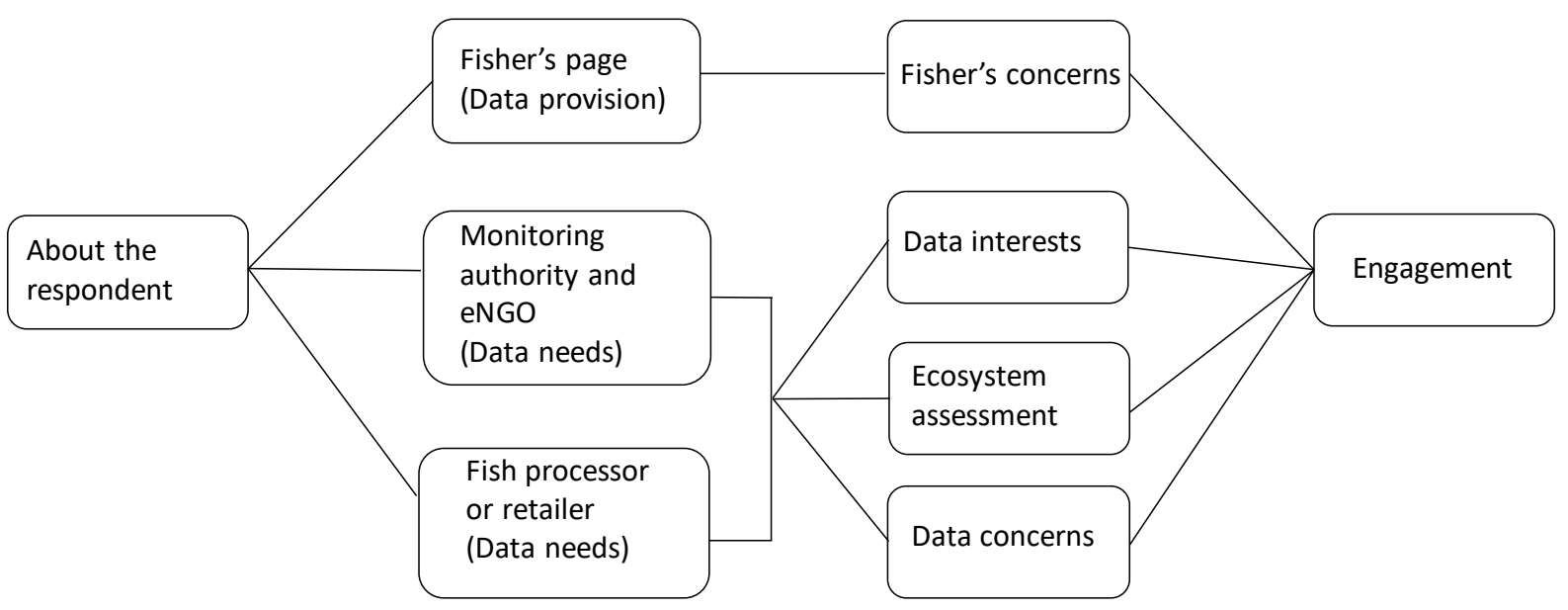

Figure 1 Schematic of the branched on-line survey identifying the questions the respondent had to answer to which determined the path through the survey. 


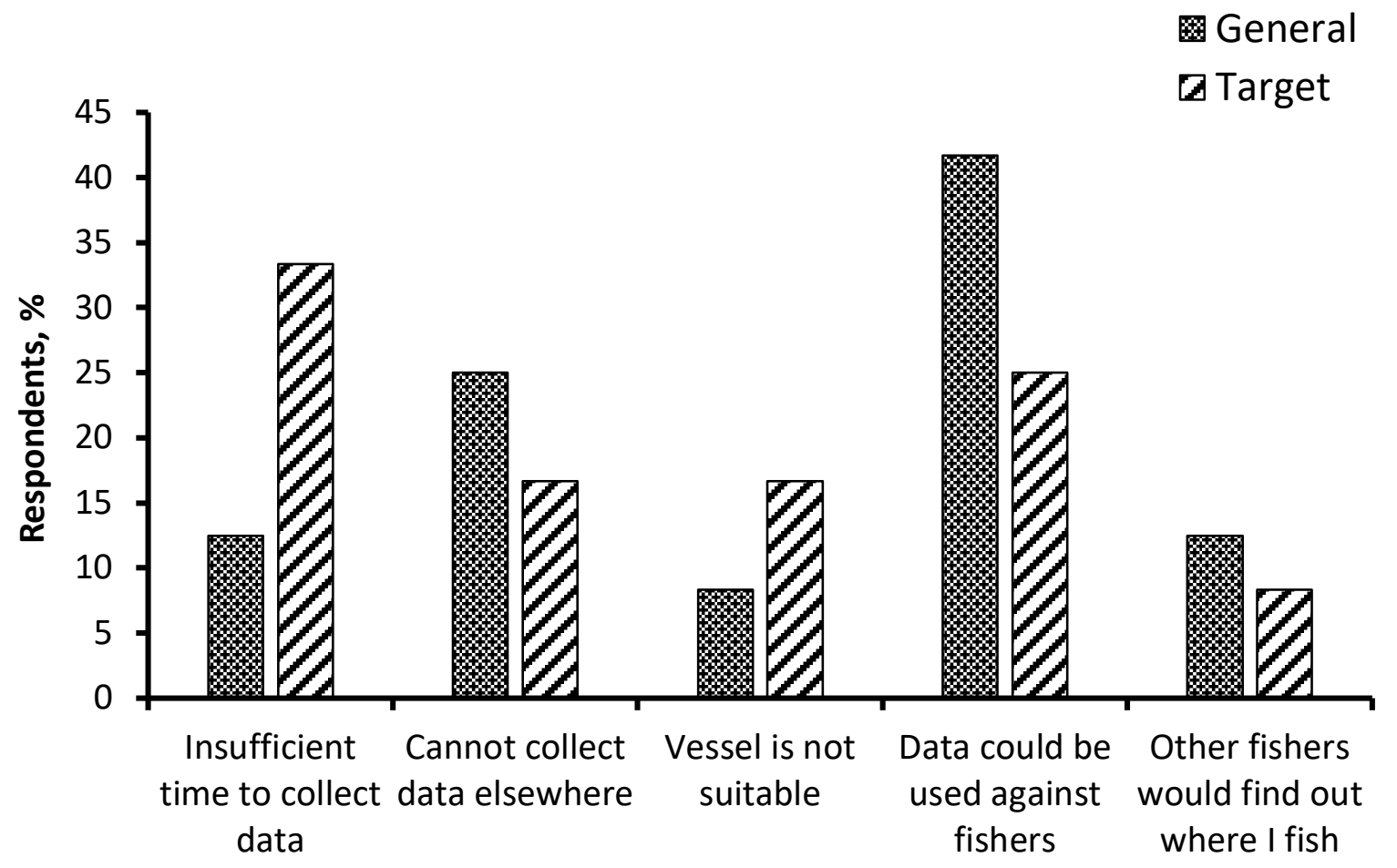

Main concern

Figure 2 Responses registered by fishers regarding concerns with data collections showing the proportion (\%) for the target and general group. 


\begin{tabular}{|c|c|c|c|c|c|}
\hline & $\begin{array}{c}1 . \\
\text { INITIATION BY CO- } \\
\text { CREATION }\end{array}$ & $\begin{array}{c}2 . \\
\text { PLANNING BY CO-DESIGN }\end{array}$ & $\begin{array}{c}3 . \\
\text { SURVEY AND ANALYSIS }\end{array}$ & $\begin{array}{c}4 . \\
\text { APPLYING THE } \\
\text { KNOWLEDGE }\end{array}$ & $\begin{array}{c}5 . \\
\text { EVALUATION }\end{array}$ \\
\hline & What do we want to achieve? & $\begin{array}{c}\text { The evidence we need and how to } \\
\text { get it }\end{array}$ & $\begin{array}{l}\text { Gathering evidence and } \\
\text { making the most of it. }\end{array}$ & $\begin{array}{l}\text { How do we make the } \\
\text { knowledge count? }\end{array}$ & $\begin{array}{c}\text { Did it achieve what was } \\
\text { expected? }\end{array}$ \\
\hline 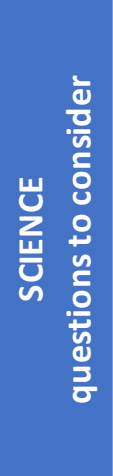 & $\begin{array}{l}\text { - What is the problem and why does } \\
\text { it need to be solved? } \\
\text { - Who wants to solve it and what } \\
\text { outcomes do they expect? } \\
\text { - What are the aims for the project? } \\
\text { - Who are the gatekeepers that will } \\
\text { influence how the evidence will be } \\
\text { applied? } \\
\text { - What is the scope, scale and timing } \\
\text { of the project? } \\
\text { - Are the outcomes achievable? }\end{array}$ & $\begin{array}{l}\text { - What objectives are needed? } \\
\text { - What information is needed for it to } \\
\text { be fit for purpose? } \\
\text { - Critical needs and constraints to } \\
\text { address? } \\
\text { - What is needed to make the data } \\
\text { robust scientifically? } \\
\text { - What skills and training are required? } \\
\text { - What are the resource implications? } \\
\text { - Who owns the data and what access } \\
\text { will they require? }\end{array}$ & $\begin{array}{l}\text { - What on-board procedures are } \\
\text { needed to make the data } \\
\text { collection work? } \\
\text { - How will the work be managed } \\
\text { to ensure quality control? } \\
\text { - How will the team and others be } \\
\text { kept up to date with progress? } \\
\text { - How will data be analysed and } \\
\text { interpreted? }\end{array}$ & $\begin{array}{l}\text { - What routes lead scientific data to } \\
\text { being used as evidence and } \\
\text { applied? } \\
\text { - What format does the data need } \\
\text { to be in for a quality review? } \\
\text { - What's required to justify any } \\
\text { proposal based on the findings? }\end{array}$ & $\begin{array}{l}\text { - Has the aim been achieved? } \\
\text { - Do the benefits outweigh } \\
\text { the costs? } \\
\text { - What worked well and what } \\
\text { can be improved? } \\
\text { - What strategic actions need } \\
\text { to occur for this to } \\
\text { continue? }\end{array}$ \\
\hline 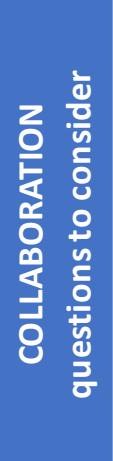 & $\begin{array}{l}\text { - Who are the end-users and } \\
\text { knowledge providers that need to } \\
\text { be involved? } \\
\text { - What understanding and } \\
\text { expectations do people have? } \\
\text { - Is the aim agreed and understood? } \\
\text { - What core values are needed to } \\
\text { make the collaboration work? } \\
\text { - Who needs to be on the project } \\
\text { team? }\end{array}$ & $\begin{array}{l}\text { - How to motivate industry's } \\
\text { participation? } \\
\text { - Who needs to be involved and how? } \\
\text { - What feedback mechanisms are } \\
\text { needed? } \\
\text { - What working practices can meet the } \\
\text { needs of the science? } \\
\text { - What research tools might help co- } \\
\text { delivery? } \\
\text { - What communications will strengthen } \\
\text { collaboration? }\end{array}$ & $\begin{array}{l}\text { - How can we build shared } \\
\text { knowledge and skills? } \\
\text { - Why is it a good idea for } \\
\text { scientists to be on board fishing } \\
\text { vessels whenever possible? } \\
\text { - How do we keep a focus on } \\
\text { getting the job done to the } \\
\text { required standard? }\end{array}$ & $\begin{array}{l}\text { - How do we gain the support of } \\
\text { relevant managers and other } \\
\text { stakeholders? } \\
\text { - What needs to be communicated } \\
\text { about the process and outcomes? } \\
\text { - Why is it important to give } \\
\text { visibility to fishermen's } \\
\text { contributions and how they have } \\
\text { been used? }\end{array}$ & $\begin{array}{l}\text { - How did the collaboration } \\
\text { process go? } \\
\text { - What was the value and } \\
\text { benefit of co-construction? } \\
\text { - Why should we give credit } \\
\text { where it is due? } \\
\text { - What should the group do } \\
\text { next? }\end{array}$ \\
\hline
\end{tabular}

Figure 3 Summary overview of the step-by-step data collection protocol showing the parallel science and collaboration processes, accompanied by the key questions to consider at each stage. 


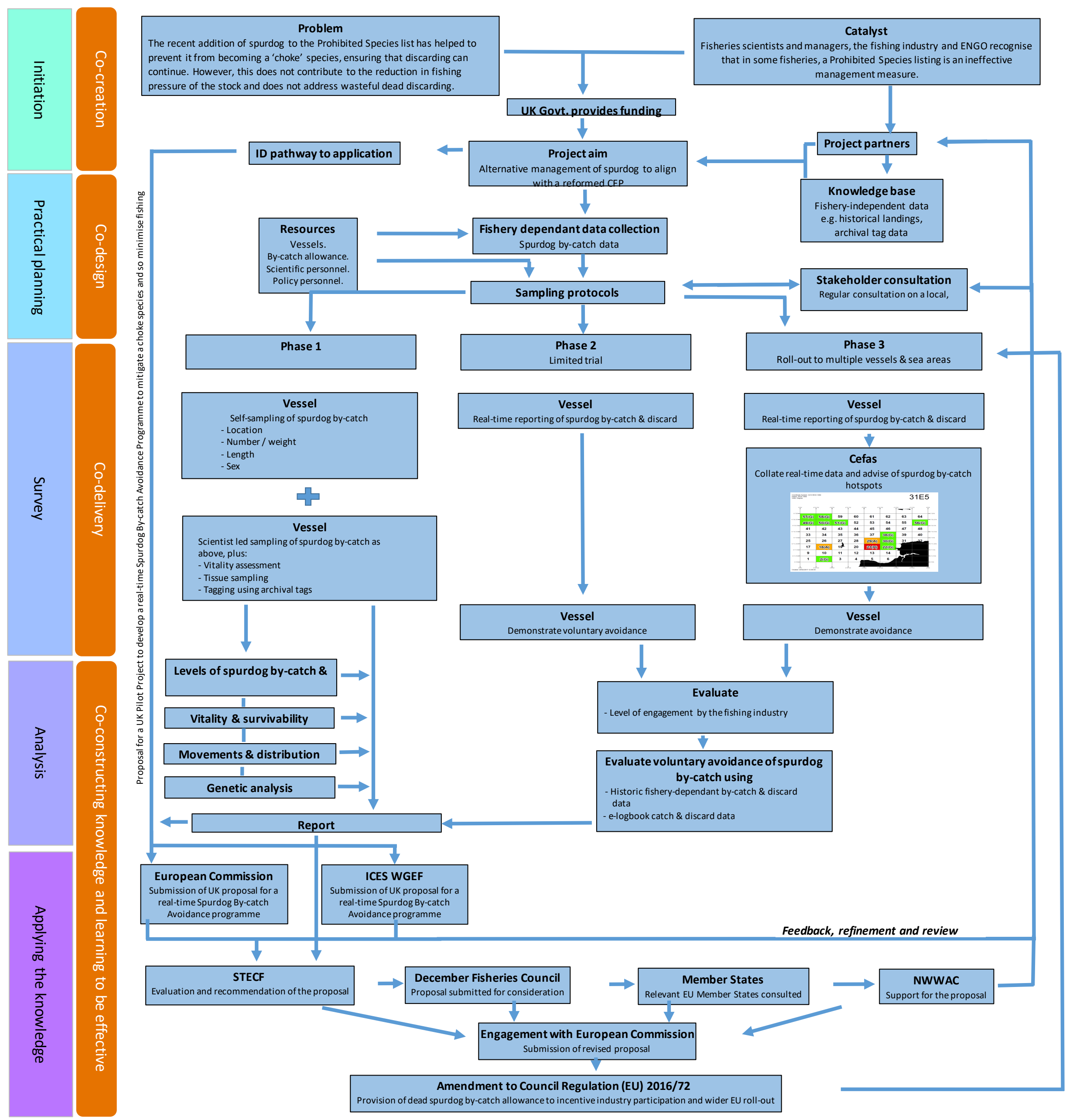

Figure 4. Architecture of the development, trail and evaluation of the real-time Spurdog by-catch avoidance programme demonstrating how the data collection guidelines can be applied to generate data and information for management. 